\title{
A global approach to obtain biobutanol from corn stover
}

\author{
María Hijosa-Valsero, a, ${ }^{*}$ Jerson Garita-Cambronero ${ }^{a}$, Ana I. Paniagua-García ${ }^{a, b}$, Rebeca Díez- \\ Antolínez ${ }^{\mathrm{a}, \mathrm{b}}$ \\ a Centro de Biocombustibles y Bioproductos, Instituto Tecnológico Agrario de Castilla y León (ITACyL), Villarejo de \\ Órbigo, 24358 León, Spain \\ b Instituto de Recursos Naturales (IRENA), Universidad de León, Avenida de Portugal 42, 24071 León, Spain \\ *Corresponding Author: María Hijosa-Valsero \\ E-mail: hijvalma@itacyl.es
}

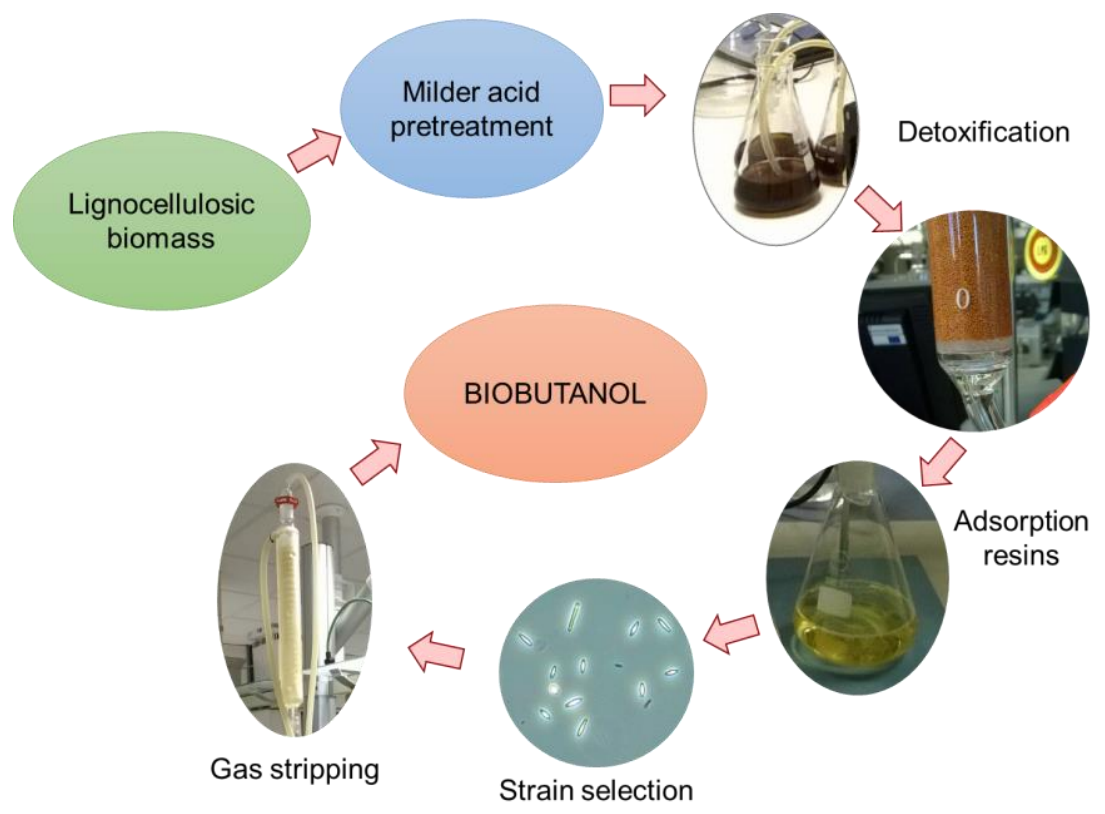

\begin{abstract}
Corn stover was subjected to a complete biorefinery process at laboratory-scale in order to obtain biobutanol. The focus was placed on process simplification, reduction of reagents and optimisation of acetone-butanol-ethanol (ABE) fermentation. The main recommendations include the use of lower acid concentrations during the physicochemical pretreatment, the selection of adequate Clostridium strains, detoxification of the hydrolysates with reusable adsorption resins and the possibility of performing gas stripping offline to recover ABE solvents. Various pretreatment conditions, fifteen bacterial strains and three polymeric adsorption resins were assessed. The proposed method consisted of a physicochemical pretreatment with $0.89 \% \mathrm{H}_{2} \mathrm{SO}_{4}(\mathrm{w} / \mathrm{w})$ at $160{ }^{\circ} \mathrm{C}$ during $5 \mathrm{~min}$, followed by an enzymatic hydrolysis, which released $75 \%$ of the sugars contained in corn stover. The hydrolysate was detoxified with the resin Dowex ${ }^{\circledR}$ Optipore ${ }^{\circledR}$ SD-2 and fermented by $C$. saccharobutylicum DSM 13864 , producing $4.75 \pm 0.25 \mathrm{~g} / \mathrm{L}$ acetone, $9.02 \pm 0.11 \mathrm{~g} / \mathrm{L}$ butanol and $0.39 \pm 0.01 \mathrm{~g} / \mathrm{L}$ ethanol in $72 \mathrm{~h}$, with a sugar consumption of $97.3 \pm$ $0.27 \%$. A two-stage gas stripping was applied to the fermentation broth, obtaining butanol-rich condensates (418-425 g/L in the organic phase) in a total time of $6 \mathrm{~h}$.
\end{abstract}

Keywords: Lignocellulosic biomass; biobutanol; corn stover; pretreatment; detoxification; Clostridium.

\section{Disclaimer:}

This PDF document is a pre-print version of the manuscript that was subsequently peer-reviewed and accepted for publication by the journal Renewable Energy (Vol. 148, pages 223-233, year 2020). The final publication is available at Elsevier via https://doi.org/10.1016/j.renene.2019.12.026. 


\section{Introduction}

The development of a sustainable industry based on the use of renewable resources to produce fuels, chemicals and environmentally friendly materials has been recognised as a key issue of importance (Sarangi and Nanda, 2018). One of the alternatives that is gathering promising scientific efforts is the study of new fuels obtained from lignocellulosic biomasses, such as butanol production through acetone-butanolethanol (ABE) fermentative process (Nanda et al., 2017).

In order to avoid the potential shortage of food that could occur by the switch from foodproducing to fuel-producing land, lignocellulosic wastes from agricultural industry have attracted much more attention as a sustainable alternative. Biobutanol production by $A B E$ fermentation has already been successfully achieved from several agricultural wastes (Gottumukkala et al., 2017; Hijosa-Valsero et al., 2017; Hijosa-Valsero et al., 2018a,b) including corn stover (Qureshi et al., 2010). Currently, this lignocellulosic biomass is one of the most important feedstocks for bioethanol production and is considered a primary feedstock for biobutanol refinery in industrialized countries such as U.S. due to its immediate availability at the required industrial scale (Baral et al., 2017). In addition, corn stover also represents an interesting feedstock to biobutanol production due to its fibrous structure with a high carbohydrate content (about 18-22\% hemicellulose and $32-36 \%$ cellulose). Both characteristics have attracted the attention of researches for using corn stover to produce second generation biobutanol (Malmierca et al., 2017).

Aside from the selection of an appropriate lignocellulosic feedstock, biobutanol production requires the improvement of a number of technical procedures before fermentation, such as biomass pretreatment and hydrolysis of structural carbohydrates, selection of a suitable bacterial strain and optimization of the physicochemical conditions in the fermentation broth ( $\mathrm{pH}, \mathrm{T}$, nutrients required, etc.) (Zhang et al., 2018). In addition, the pretreatment processes -because of sugars and lignin degradation- produce chemical by-products (phenolic compounds, furan derivatives and weak organic acids) which cause inhibition on solventogenic strains of Clostridium affecting biobutanol production (Grisales and Olivar, 2018). The production of these inhibitors is enhanced mainly under dilute acid pretreatments, particularly when using sulfuric acid (Baral and Shah, 2014). In order to deal with this drawback, several studies have proposed a wide range of alternatives to detoxify corn stover hydrolysates prior to bacterial fermentation. These methods include inhibitors extraction, adsorption, evaporation, electrodialysis, overliming, neutralization, steam stripping, as well as enzymatic and microbial treatments (Grisales and Olivar, 2018). Among the adsorption methods, the use of polymeric resins has been determined as an efficient method to detoxify biomassic hydrolysates, as well as a technique to remove alcohols from the fermentation broth (Carvalho et al., 2004; Gao and Rehman, 2016). In addition, polymeric resins potentiate the reduction of the overall production cost due to their reusability without affecting the process efficiency and in some cases without altering the sugar concentration contained in the hydrolysate (Gao and Rehmann, 2016).

Previous studies on biobutanol production from corn stover have tried to solve each one of the abovementioned parameters through the selection of mutant and wild type solventogenic Clostridium strains (Liu et al., 2017; Qureshi et al., 2010; Tang et al., 2017; Wang and Chen, 2011; Xue et al., 2016a; Zhang et al., 2018); the use of different pretreatment reagents and conditions (Baral and Shah, 2017; Tang et al., 2017; Xue et al., 2016a; Zhang et al., 2014) and hydrolysate detoxification by various methods (Liu et al., 2017; Qureshi et al., 2010; 2014; Tang et al., 2017; Wang and Chen, 2011; Xue et al., 2016a; Zhang et al., 2018). Currently, studies conducted to potentiate biobutanol industrial production from corn stover are clearly required to increase yield values, but also to reduce the associated economic costs. Therefore, using alternatives such as an optimum biomass pretreatment with sulfuric acid or testing other detoxification techniques such as reusable resins, could decrease the economic and energetic requirements associated with the $A B E$ fermentative process (Baral and Shah, 2017). 
From an economic and energetic point of view, downstream processes such as solvent recovery and purification from fermentation broths are extremely important in biorefineries. The application of integrated recovery processes (which remove acetone, butanol and ethanol as they are being produced in the fermentation broth), like gas stripping, liquid-liquid extraction, vacuum fermentation, adsorption, reverse osmosis, pervaporation and perstraction, has been extensively reviewed (Abdehagh et al., 2014; Outram et al., 2016; Staggs and Nielsen, 2015; Xue et al., 2014; Xue et al., 2017). Recently, gas stripping has emerged as a very attractive alternative, since its energy requirements (including a final step of distillation) could be lower than previously calculated (Patraşcu et al., 2017; Xue et al., 2013a; Xue et al., 2013b; Xue et al., 2016b) and also due to configuration innovations like two-stage gas stripping (Xue et al., 2013a). Gas stripping has been usually tested as an integrated (in situ) recovery technique; but these types of operating conditions can increase the whole process energy requirements (Outram et al., 2016). It has been observed that gas stripping is also successful when applied once that the fermentation is finished, which requires much shorter stripping times (de Vrije et al., 2013).

In view of the above, in this paper different strategies will be explored to deal with most of the major drawbacks that are present at each step of the ABE fermentative process when using corn stover as lignocellulosic feedstock. Consequently, acid pretreatment conditions will be refined in order to obtain suitable sugar and inhibitor concentrations in the hydrolysate, followed by a clostridial strain selection and the optimization of certain fermentation conditions $\left(\mathrm{pH}, \mathrm{T}, \mathrm{CaCO}_{3}\right.$ and nutrient supplementation). The necessity of a detoxification process to remove inhibitors by inert adsorption resins prior to fermentation will be evaluated. Finally, the $A B E$ solvents contained in the fermentation broth will be recovered by two-stage gas stripping. To the best of our knowledge, this is the first time that a complete ABE biorefinery process based on corn stover has been successfully developed, including a detoxification step with reusable resins.

\section{Material and methods}

\subsection{Chemicals and reagents}

Analytical grade $\mathrm{H}_{2} \mathrm{SO}_{4}, \mathrm{HNO}_{3}, \mathrm{HCl}, \mathrm{NaOH}$, $\mathrm{K}_{2} \mathrm{HPO}_{4}$ and $\mathrm{KH}_{2} \mathrm{PO}_{4}$ were obtained from Panreac (Castellar del Vallès, Spain). Citric acid anhydrous, yeast extract, $\mathrm{NH}_{4} \mathrm{Cl}, \mathrm{FeSO}_{4} \cdot 7 \mathrm{H}_{2} \mathrm{O}$, $\mathrm{MgSO}_{4} \cdot 7 \mathrm{H}_{2} \mathrm{O}, \mathrm{MnSO}_{4} \cdot \mathrm{H}_{2} \mathrm{O}, \mathrm{ZnSO}_{4} \cdot 7 \mathrm{H}_{2} \mathrm{O}$, cysteine and $\mathrm{CaCO}_{3}$ were purchased from Sigma-Aldrich (Steinheim, Germany). The enzyme Cellic CTec2 (enzymatic activity $105 \mathrm{FPU} / \mathrm{mL}$ ) was provided by Novozymes (Tianjin, China). The polymeric resin Amberlite ${ }^{\circledR}$ XAD-4 was bought from Acros Organics (Geel, Belgium), Dowex ${ }^{\circledR}$ Optipore ${ }^{\circledR}$ L493 was purchased from Sigma-Aldrich (St. Louis, MO, USA) and Dowex ${ }^{\circledR}$ Optipore ${ }^{\circledR}$ SD-2 was obtained from Supelco (Bellefonte, PA, USA).

\subsection{Biomass description}

Corn stover samples were obtained in November 2017 from experimental plots (ITACyL, Finca Zamadueñas, Valladolid, Spain). These agricultural by-products were dried in an oven at $45{ }^{\circ} \mathrm{C}$ until constant weight, ground in a rotary mill SM100 Comfort (Retsch GmbH, Haan, Germany) and sieved to a size of $0.5-1.0 \mathrm{~mm}$. Moisture, ash, structural carbohydrates (cellulose and hemicellulose), Klason lignin, fats, proteins and total phenolic compounds were analysed as reported elsewhere (Hijosa-Valsero et al., 2017). Corn stover composition is shown in Table 1.

Table 1. Chemical composition of corn stover. Note: Xylan comprises xylan, galactan and mannan.

\begin{tabular}{|l|c|}
\hline & Corn stover \\
\hline Total carbohydrates (\%) & 57.23 \\
\hline Soluble sugars (\%) & 2.00 \\
\hline Glucan/Cellulose (\%) & 31.93 \\
\hline Hemicellulose (\%) & 17.40 \\
\hline - Xylan (\%) & 15.54 \\
\hline - Arabinan (\%) & 1.90 \\
\hline Klason lignin (\%) & 15.15 \\
\hline Protein (\%) & 3.29 \\
\hline Fat (\%) & 0.57 \\
\hline Moisture (\%) & 12.45 \\
\hline Ashes (\%) & 5.36 \\
\hline Phenolic compounds (mg/g) & 6.1 \\
\hline
\end{tabular}

\subsection{Physicochemical pretreatment}

Corn stover was subjected to a dilute-acid physicochemical pretreatment. It was checked that autohydrolysis was not an efficient pretreatment for corn stover (data not shown). In preliminary tests, nitric acid and sulfuric acid 
were assessed under similar conditions [pretreatment at $0.89 \%(\mathrm{w} / \mathrm{w})$ acid, $125^{\circ} \mathrm{C}, 5 \mathrm{~min}$; followed by enzymatic hydrolysis], and finally sulfuric acid was chosen for the subsequent experiments because its hydrolysates were more easily fermentable by bacteria (Figure A1).

Physicochemical pretreatments were carried out with a 2-L high-pressure reactor made of alloy Carpenter-20 (Parr Instrument Company, Moline, $\mathrm{IL}$, USA). Corn stover was immersed in an aqueous solution of sulfuric acid, with a solid-tosolvent ratio of $10 \%(\mathrm{w} / \mathrm{w})$. Operation details of the reactor are described elsewhere (HijosaValsero et al., 2018a). After the thermal pretreatment, an enzymatic hydrolysis was performed on the solid/liquid mixture obtained in the reactor according to the procedure described in section 2.4.

\subsection{Pretreatment optimisation}

The physicochemical pretreatment was optimised in order to obtain a fermentable broth with the maximum concentration of simple sugars (glucose, xylose, etc.) and the minimum concentration of inhibitors [formic acid, acetic acid, levulinic acid, furfural, 5-hydroxymethyl furfural (5-HMF) and phenolic compounds]. Although the analysis of sugars and inhibitors was performed after the combined and subsequent steps of physicochemical pretreatment and enzymatic hydrolysis, the process optimization was focused on physicochemical pretreatment conditions, because they are responsible for the generation of inhibitors and have a great influence on sugar release during enzymatic hydrolysis. In particular, the variables to be optimized were $\mathrm{H}_{2} \mathrm{SO}_{4}$ concentration $(0.89,1.13,1.37,1.60$ and $1.84 \%$ w/w) and temperature (125, 135, 145 and 160 $\left.{ }^{\circ} \mathrm{C}\right)$. The treatment time in the reactor was experimentally set at $5 \mathrm{~min}$, after checking that longer treatment times did not improve sugar release.

\subsection{Enzymatic hydrolysis}

After the thermal pretreatment, an enzymatic hydrolysis with Cellic CTec 2 was performed on the biomass solid/liquid mixture obtained in the reactor, following the method described by (Hijosa-Valsero et al., 2017). The employed dose of $36 \mu \mathrm{L} / \mathrm{g}$ biomass is equivalent to $3.78 \mathrm{FPU} / \mathrm{g}$ biomass.

\subsection{Strain cultivation}

The strains Clostridium acetobutylicum DSM 792, DSM 1732, DSM 6228, C. beijerinckii DSM 51, DSM 552, DSM 791, DSM 1820, DSM 6422, DSM 6423, C. pasteurianum DSM 526, C. saccharobutylicum DSM 13864, C. saccharoperbutylacetonicum DSM 2152 and DSM 14923 were purchased from Deutsche Sammlung von Mikroorganismen und Zellkulturen (Braunschweig, Germany), whereas the strain C. acetobutylicum NRRL B-530 was obtained from the ARS Culture Collection NRRL (Peoria, IL, USA) and the strain $C$. beijerinckii CECT 508 was supplied by CECT (Paterna, Spain). Spores from all the strains (except DSM 6228) were prepared and stored as explained in (Paniagua-García et al., 2018). For the asporogenic strain DSM 6228, lyophilised cells were resuspended in $10 \mathrm{~mL}$ of sterile Reinforced Clostridial Medium - RCM (Oxoid, Basingstoke, UK) supplemented with $10 \mathrm{~g} / \mathrm{L}$ glucose, and incubated $24 \mathrm{~h}$ at $35{ }^{\circ} \mathrm{C}$ under anaerobic conditions. Then, $1.5 \mathrm{~mL}$ were mixed with $0.4 \mathrm{~mL}$ glycerol $(80 \% \mathrm{v} / \mathrm{v})$ in a cryogenic vial and stored at $-80{ }^{\circ} \mathrm{C}$ until being used. Cellular reactivation and innocula preparation were performed in liquid RCM or in a potato based medium (in the case of DSM 2152 and DSM 792) as detailed by Hijosa-Valsero et al. (2018b). Bacterial cultures were incubated for $20-48 \mathrm{~h}$ at $35^{\circ} \mathrm{C}$ in order to obtain a density of $5 \cdot 10^{8}$ cells $/ \mathrm{mL}$ as determined by counting in a Bürker chamber (Paul Marienfeld GmbH \& Co. KG, Lauda-Königshofen, Germany).

\subsection{Strain selection for the fermentation of corn stover hydrolysates}

Corn stover hydrolysates were obtained after a pretreatment with $\mathrm{H}_{2} \mathrm{SO}_{4}\left(125{ }^{\circ} \mathrm{C}, 5 \mathrm{~min}, 0.89 \%\right.$ $\mathrm{w} / \mathrm{w}$ acid) and a subsequent enzymatic hydrolysis. For fermentation tests, nondetoxified corn stover hydrolysates were filtered through filter paper (No. 1305, $73 \mathrm{~g} / \mathrm{m}^{2}$, Filtros Anoia SA, Barcelona, Spain) and supplemented with the standard nutrients (S) listed in Table 2. Inoculation and medium preparation were performed as described by Paniagua-García et al. (2018). Fermentations were conducted at 35 ${ }^{\circ} \mathrm{C}, 100 \mathrm{rpm}$ and $96 \mathrm{~h}$ in an Infors HT Minitron orbital shaker (Infors AG, Bottmingen, Switzerland). These experiments were performed 
in triplicate with the fifteen bacterial strains listed in section 2.5. Fermentation controls were prepared with aqueous solutions containing glucose and xylose mixtures at similar concentrations to those of corn stover hydrolysates, and supplemented with the abovementioned nutrients and salts. The most appropriate strain was selected for the next experiments.

Table 2. Different nutrient supplementation and fermentation conditions applied to corn stover hydrolysates.

\begin{tabular}{|c|c|c|}
\hline & Standard (S) & Optimised (0) \\
\hline \multicolumn{3}{|l|}{ Nutrients } \\
\hline Yeast extract (g/L) & 5 & 5 \\
\hline $\mathrm{KH}_{2} \mathrm{PO}_{4}(\mathrm{~g} / \mathrm{L})$ & 1 & 1 \\
\hline $\mathrm{K}_{2} \mathrm{HPO}_{4}(\mathrm{~g} / \mathrm{L})$ & 0 & 1 \\
\hline $\mathrm{NH}_{4} \mathrm{Cl}(\mathrm{g} / \mathrm{L})$ & 2.1 & 2.1 \\
\hline $\mathrm{MgSO}_{4} \cdot 7 \mathrm{H}_{2} \mathrm{O}(\mathrm{g} / \mathrm{L})$ & 0.2 & 0.2 \\
\hline $\mathrm{FeSO}_{4} \cdot 7 \mathrm{H}_{2} \mathrm{O}(\mathrm{g} / \mathrm{L})$ & 0.01 & 0.01 \\
\hline $\mathrm{MnSO}_{4} \cdot 7 \mathrm{H}_{2} \mathrm{O}(\mathrm{g} / \mathrm{L})$ & 0 & 0.01 \\
\hline Cysteine (g/L) & 0.5 & 0 \\
\hline $\mathrm{CaCO}_{3}(\mathrm{~g} / \mathrm{L})$ & 5 & 8 \\
\hline \multicolumn{3}{|c|}{ Fermentation conditions } \\
\hline Temperature $\left({ }^{\circ} \mathrm{C}\right)$ & 35 & 28 \\
\hline Initial pH & 6.00 & 5.42 \\
\hline Shaking (rpm) & 100 & 100 \\
\hline
\end{tabular}

\subsection{Optimisation of fermentation conditions}

Once that the most efficient strain had been selected, the most adequate nutrients and fermentation conditions for that strain were determined. In the first place, a Plackett-Burman experimental design was proposed to select the necessary nutrients and their concentrations. Corn stover was pretreated with $\mathrm{H}_{2} \mathrm{SO}_{4}\left(125^{\circ} \mathrm{C}\right.$, 5 $\min , \quad 0.89 \%$ acid $\mathrm{w} / \mathrm{w}$ ) and a subsequent enzymatic hydrolysis. The Plackett-Burman design consisted of twelve experimental runs combining the maximum and minimum values established for the ten independent variables (ten nutrients: yeast extract, $\mathrm{KH}_{2} \mathrm{PO}_{4}, \mathrm{~K}_{2} \mathrm{HPO}_{4}$, $\mathrm{NH}_{4} \mathrm{Cl}, \mathrm{MgSO}_{4} \cdot 7 \mathrm{H}_{2} \mathrm{O}, \mathrm{FeSO}_{4} \cdot 7 \mathrm{H}_{2} \mathrm{O}, \mathrm{MnSO}_{4} \cdot \mathrm{H}_{2} \mathrm{O}$, $\mathrm{ZnSO}_{4} \cdot 7 \mathrm{H}_{2} \mathrm{O}$, cysteine and $\left.\mathrm{CaCO}_{3}\right)$. The hydrolysates were fermented under the conditions described in section 2.6 and butanol was measured as the response variable. The characteristics of this experimental design are shown in Table A1. The nutrients and their concentration ranges were selected according to literature data (Liu et al., 2017; Qureshi and Blaschek, 1999; Qureshi et al., 2014; Ujor et al., 2016).
In the second place, after having established the essential nutrients for the selected strain, fermentation conditions (temperature, initial $\mathrm{pH}$ and $\mathrm{CaCO}_{3}$ concentration for $\mathrm{pH}$ control) were optimised via response surface methodology (RSM) with a Box-Behnken experimental design consisting of 3 factors, 1 replicate, 15 runs, 1 block and 3 central points (Table A4). Corn stover was pretreated with $\mathrm{H}_{2} \mathrm{SO}_{4}\left(125^{\circ} \mathrm{C}\right.$, 5 min, $0.89 \%$ acid $\mathrm{w} / \mathrm{w}$ ) and a subsequent enzymatic hydrolysis, and then it was fermented using the nutrients and fermentation conditions listed in Table A4.

\subsection{Detoxification}

The objective of pretreatment and fermentation optimisation was to obtain high sugar concentrations and low inhibitor concentrations in order to directly ferment corn stover hydrolysates, thus avoiding an expensive detoxification step to remove inhibitors. However, the severe pretreatments applied to this lignocellulosic biomass could require a detoxification process. The polymeric adsorption resins Amberlite ${ }^{\circledR}$ XAD-4, Dowex ${ }^{\circledR}$ Optipore ${ }^{\circledR}$ L-493 and Dowex ${ }^{\circledR}$ Optipore ${ }^{\circledR}$ SD-2 were evaluated for the removal of inhibitors from corn stover hydrolysates. About $58 \mathrm{~g}$ of each polymeric resin were placed inside a $120-\mathrm{mL}$ glass column (chromatography column with soldered porous plate No. 0, model 340634, 400 $\mathrm{mm} \times 20 \mathrm{~mm}$ i.d.; Pobel, Madrid, Spain) and they were soaked with distilled water, reaching a total volume of $90 \mathrm{~mL}$. The resins were conditioned following a modification of (Schwartz and Lawoko, 2010). In brief, the resin Amberlite ${ }^{\circledR}$ XAD-4 was washed three times with $90 \mathrm{~mL}$ methanol at $4 \mathrm{~mL} / \mathrm{min}$ and then was left in methanol overnight. Afterwards it was washed with $900 \mathrm{~mL}$ distilled water at $10 \mathrm{~mL} / \mathrm{min}$. The resins Dowex ${ }^{\circledR}$ Optipore ${ }^{\circledR}$ L-493 and Dowex ${ }^{\circledR}$ Optipore ${ }^{\circledR}$ SD-2 were washed three times with $90 \mathrm{~mL} \mathrm{NaOH} 1 \mathrm{M}$ at $4 \mathrm{~mL} / \mathrm{min}$ and then with 900 $\mathrm{mL}$ distilled water at $10 \mathrm{~mL} / \mathrm{min}$.

For the detoxification step, corn stover (10\% solid biomass) was pretreated with a $0.89 \%$ $\mathrm{H}_{2} \mathrm{SO}_{4} \mathrm{w} / \mathrm{w}$ aqueous solution during $5 \mathrm{~min}$. Two distinct pretreatment temperatures $\left(125{ }^{\circ} \mathrm{C}\right.$ or $160{ }^{\circ} \mathrm{C}$ ) had to be tested in order to generate different sugar concentrations in the hydrolysate (see section 3.4). Then, a subsequent enzymatic hydrolysis was applied. The hydrolysate was 
passed through filter paper (No. 1305, $73 \mathrm{~g} / \mathrm{m}^{2}$, Filtros Anoia SA, Barcelona, Spain), and its $\mathrm{pH}$ was adjusted to 5.42 (optimal $\mathrm{pH}$ for fermentation). Then, the hydrolysate was fed into the column at a rate of $2 \mathrm{~mL} / \mathrm{min}$ using a peristaltic pump (10 min residence time). The detoxified hydrolysate was collected and fermented with C. saccharobutylicum DSM 13864 under the optimal conditions $(\mathrm{O})$ described in Table 2. The use of other strains for detoxified hydrolysates was experimentally discarded (see Appendix and Figure A2).

\subsection{Gas stripping}

In order to recover solvents (acetone, butanol and ethanol) from the fermentation broths, a two-stage gas stripping was applied according to Díez-Antolínez et al. (2018). Corn stover hydrolysate was obtained by treating $10 \%$ solid biomass in an aqueous solution of $0.89 \% \mathrm{H}_{2} \mathrm{SO}_{4}$ $(\mathrm{w} / \mathrm{w})$ at $160^{\circ} \mathrm{C}$ during $5 \mathrm{~min}$, followed by enzymatic hydrolysis and detoxification with the resin Dowex ${ }^{\circledR}$ Optipore ${ }^{\circledR}$ SD-2. The hydrolysate was fermented by $C$. saccharobutylicum DSM 13864 during $72 \mathrm{~h}$ using the optimised combination $(\mathrm{O})$ described in Table 2.

About $3.2 \mathrm{~L}$ of fermentation broth containing $5.02 \mathrm{~g} / \mathrm{L}$ acetone, $9.02 \mathrm{~g} / \mathrm{L}$ butanol, $0.42 \mathrm{~g} / \mathrm{L}$ ethanol, $1.61 \mathrm{~g} / \mathrm{L}$ acetic acid, $0.95 \mathrm{~g} / \mathrm{L}$ butyric acid and $1.19 \mathrm{~g} / \mathrm{L}$ total sugars, were subjected to gas stripping during $5 \mathrm{~h}$ under the following conditions: $T_{\text {feed }}=60{ }^{\circ} \mathrm{C}, T_{\text {refrigeration }}=5{ }^{\circ} \mathrm{C}$ and gas flow $=1.34 \mathrm{~L} / \mathrm{min}$. Five millilitres of Antifoam A (Fluka Analytical, Sigma-Aldrich, Steinheim, Germany) were added to the fermentation broth at the beginning of the stripping to avoid foam formation. The condensate was collected and it separated spontaneously in two phases (organic and aqueous). The aqueous phase was further subjected to another gas stripping process during $1 \mathrm{~h}$ and its condensate was collected.

The performance of the gas stripping process was calculated based on solvent recovery $(\eta)$ and selectivity $(\alpha)$, according to Equations 1 and 2 (Fu et al., 2016; Lu et al., 2016):

$$
\begin{gathered}
\eta_{i}=\frac{m_{i c}}{m_{i F}} \\
\alpha_{i}=\frac{\frac{y_{i}}{1-y_{i}}}{\frac{x_{i}}{1-x_{i}}}
\end{gathered}
$$

where $\alpha_{\mathrm{i}}$ is the selectivity for compound $i$ (for instance, butanol; $\left.\alpha_{B}\right), x_{i}$ is the mass ratio of metabolite $i$ in the feed solution, $y_{i}$ is the mass ratio of metabolite $i$ in the condensate, $\eta_{i}$ is the percentage recovery efficiency for metabolite $i$ (in this case, butanol; $\eta_{B}$ ), $m_{i c}$ is the mass of metabolite $i$ in the condensate (expressed in $\mathrm{g}$ ) and $m_{\mathrm{iF}}$ is the mass of metabolite $i$ in the feed solution. Gas stripping rates $[g /(L \cdot h)]$ were calculated as proposed by Truong and Blackburn (1984).

\subsection{Chemical analyses}

Hydrolysate and fermentation aqueous samples were analysed according to Hijosa-Valsero et al. (2017). In brief, the sugars cellobiose, glucose, xylose, rhamnose and arabinose, and the potential inhibitors formic acid, acetic acid, levulinic acid, 5-HMF and furfural were analysed by HPLC-RID; phenolic compounds were analysed by Folin-Denis' assay; whereas fermentation metabolites, like acetone, butanol, ethanol, isopropanol, acetic acid and butyric acid were determined by GC-FID.

Fermentation yields $\left(Y_{i / s}, g / g\right)$, metabolite productivity rates $\left[\mathrm{W}_{\mathrm{i},} \mathrm{g} /(\mathrm{L} \cdot \mathrm{h})\right]$ and sugar recovery or sugar conversion efficiency (\%) were calculated as explained elsewhere (HijosaValsero et al., 2018b).

\subsection{Statistical analyses}

Samples were compared with a one-way ANOVA and Tukey's HSD test using the software Statistica 7 (StatSoft Inc., Tulsa, OK, USA). Plackett-Burman experimental designs and BoxBehnken RSM experimental designs were made with the software Minitab 16 (Minitab Inc., State College, PA, USA).

\section{Results}

\subsection{Composition of corn stover hydrolysates}

The effects of temperature and $\mathrm{H}_{2} \mathrm{SO}_{4}$ concentration on corn stover pretreatment were assessed in order to increase sugar release and minimise the generation of fermentation inhibitors. Table 3 shows the chemical composition of various corn stover hydrolysates obtained with different pretreatment conditions. It was observed that temperature had a clear direct effect both on sugar release and inhibitor formation when acid concentration was kept 
constant at $0.89 \% \mathrm{w} / \mathrm{w}$ (Table 3 ). On the contrary, for a fixed temperature of $125^{\circ} \mathrm{C}$, an increase in $\mathrm{H}_{2} \mathrm{SO}_{4}$ concentration did not improve sugar release, but slightly favoured the generation of inhibitors, specially formic acid, acetic acid, furfural and phenolic compounds (Table 3). These data suggest that a sulfuric acid concentration of $0.89 \% \mathrm{w} / \mathrm{w}$ (which is equivalent to $\sim 0.54 \% \mathrm{v} / \mathrm{v}$ ) could be sufficient for corn stover degradation. In fact, Gao and Rehman (2016) pretreated Phragmites australis with increasing concentrations of $\mathrm{H}_{2} \mathrm{SO}_{4}(0.5-2.0 \% \mathrm{v} / \mathrm{v})$ and they observed that the use of higher acid concentrations did not release more sugars, but only more inhibitors. In addition, they reported that $\mathrm{H}_{2} \mathrm{SO}_{4}$ concentration influenced the type of phenolic compounds generated.

The amount of total sugars released from corn stover ranged between 34.7 and $50.4 \mathrm{~g} / \mathrm{L}$, depending on the physicochemical pretreatment used (Table 3), which implies a sugar recovery efficiency of $48-75 \%$. According to a review published by Baral and Shah (2014), the sugar yields obtained from corn stover employing different pretreatment methods vary between 42 and $66 \mathrm{~g}$ of fermentable sugars per $100 \mathrm{~g}$ of dry corn stover. In the present study, as corn stover contained $57.23 \%$ carbohydrates (Table 1), that yield would reach $\sim 43 \mathrm{~g}$ of fermentable sugars per $100 \mathrm{~g}$ of dry corn stover in the best case.

In order to avoid inhibitory problems, it was decided to select the pretreatment conditions of $0.89 \% \mathrm{H}_{2} \mathrm{SO}_{4} \mathrm{w} / \mathrm{w}, 125{ }^{\circ} \mathrm{C}$ and $5 \mathrm{~min}$, because they offered acceptable sugar concentrations and low inhibitor concentrations. The total sugar concentration obtained ( 40 g/L), moderate as it may seem, might guarantee successful $A B E$ fermentations, as observed in previous works with cheese whey (Díez-Antolínez et al., 2016) or coffee silverskin (Hijosa-Valsero et al., 2018b), where initial sugar concentrations as low as 30$34 \mathrm{~g} / \mathrm{L}$ enabled the generation of 7.0-8.5 $\mathrm{g} / \mathrm{L}$ biobutanol.

Table 3. Composition of corn stover hydrolysates after $\mathrm{H}_{2} \mathrm{SO}_{4}$ pretreatment and enzymatic hydrolysis under various temperature and acid concentrations in the physicochemical pretreatment. $\left(^{*}\right)$ Note: Figures between brackets indicate the percentage of sugar recovery considering the total carbohydrate content of corn stover.

\begin{tabular}{|c|c|c|c|c|c|c|c|c|c|}
\hline \multirow[b]{2}{*}{$\begin{array}{l}\text { Concentration } \\
\text { (g/L) }\end{array}$} & \multicolumn{4}{|c|}{$\begin{array}{l}\text { Physicochemical pretreatment }\left(0.89 \% \mathrm{H}_{2} \mathrm{SO}_{4}, 5\right. \\
\text { min) + Enzymatic hydrolysis }\end{array}$} & \multicolumn{5}{|c|}{$\begin{array}{l}\text { Physicochemical pretreatment }\left(125^{\circ} \mathrm{C}, 5 \mathrm{~min}\right)+\text { Enzymatic } \\
\text { hydrolysis }\end{array}$} \\
\hline & $125^{\circ} \mathrm{C}$ & $135^{\circ} \mathrm{C}$ & $145^{\circ} \mathrm{C}$ & $160^{\circ} \mathrm{C}$ & $\begin{array}{l}0.89 \% \\
\mathrm{H}_{2} \mathrm{SO}_{4}\end{array}$ & $\begin{array}{l}1.13 \% \\
\mathrm{H}_{2} \mathrm{SO}_{4}\end{array}$ & $\begin{array}{l}1.37 \% \\
\mathrm{H}_{2} \mathrm{SO}_{4}\end{array}$ & $\begin{array}{l}1.60 \% \\
\mathrm{H}_{2} \mathrm{SO}_{4}\end{array}$ & $\begin{array}{l}1.84 \% \\
\mathrm{H}_{2} \mathrm{SO}_{4}\end{array}$ \\
\hline \multicolumn{10}{|l|}{ Sugars } \\
\hline Cellobiose & 1.36 & 1.59 & 1.87 & 1.18 & 1.36 & 1.38 & 1.17 & 1.33 & 0.21 \\
\hline Glucose & 21.7 & 20.8 & 23.32 & 29.77 & 21.7 & 20.7 & 19.1 & 21.1 & 17.9 \\
\hline Xylose & 15.7 & 15.51 & 17.66 & 17.75 & 15.7 & 15.1 & 14.3 & 15.7 & 14.6 \\
\hline Rhamnose & $<0.05$ & $<0.05$ & $<0.05$ & $<0.05$ & $<0.05$ & $<0.05$ & $<0.05$ & $<0.05$ & 0.14 \\
\hline Arabinose & 1.69 & 1.82 & 1.76 & 1.67 & 1.69 & 1.77 & 1.73 & 1.8 & 1.85 \\
\hline Total sugars* & $\begin{array}{c}40.5 \\
(61 \%)\end{array}$ & $\begin{array}{c}39.7 \\
(59 \%)\end{array}$ & $\begin{array}{c}44.6 \\
(66 \%)\end{array}$ & $\begin{array}{c}50.4 \\
(75 \%)\end{array}$ & $\begin{array}{l}40.5 \\
(61 \%)\end{array}$ & $\begin{array}{c}39.0 \\
(56 \%)\end{array}$ & $\begin{array}{c}36.3 \\
(54 \%)\end{array}$ & $\begin{array}{c}40.0 \\
(59 \%)\end{array}$ & $\begin{array}{c}34.7 \\
(48 \%)\end{array}$ \\
\hline \multicolumn{10}{|l|}{ Inhibitors } \\
\hline Formic acid & 0.08 & 0.10 & 0.14 & 0.17 & 0.08 & 0.09 & 0.09 & 0.12 & 0.12 \\
\hline Acetic acid & 2.47 & 2.6 & 2.93 & 3.25 & 2.47 & 2.52 & 2.44 & 2.73 & 2.95 \\
\hline Levulinic acid & $<0.02$ & $<0.02$ & 0.04 & 0.09 & $<0.02$ & 0.03 & 0.03 & 0.04 & 0.05 \\
\hline 5-HMF & 0.16 & 0.12 & 0.23 & 0.43 & 0.16 & 0.08 & 0.09 & 0.11 & 0.09 \\
\hline Furfural & 0.05 & 0.07 & 0.22 & 0.64 & 0.05 & 0.08 & 0.08 & 0.10 & 0.12 \\
\hline $\begin{array}{l}\text { Phenolic } \\
\text { compounds }\end{array}$ & 1.06 & 1.09 & 1.12 & 1.24 & 1.06 & 1.15 & 1.19 & 1.23 & 1.38 \\
\hline
\end{tabular}




\subsection{Strain comparison for corn stover}

\section{hydrolysates}

Different bacterial strains were compared for the fermentation of corn stover hydrolysates after pretreating this biomass at $125^{\circ} \mathrm{C}$, during $5 \mathrm{~min}$ with $0.89 \% \mathrm{w} / \mathrm{w} \mathrm{H}_{2} \mathrm{SO}_{4}$ and subjecting the sample to enzymatic hydrolysis. The results of the fermentation experiments are shown in Figure 1.

The best fermentations were performed by the strains DSM 13864 (5.95 $\pm 0.06 \mathrm{~g} / \mathrm{L}$ butanol, $94 \pm$ $0.3 \%$ total sugar consumption), DSM 6423 (5.49 $\pm 0.20 \mathrm{~g} / \mathrm{L}$ butanol, $78 \pm 2.4 \%$ total sugar consumption) and DSM 2152 (4.97 $\pm 0.33 \mathrm{~g} / \mathrm{L}$ butanol, $80 \pm 2.1 \%$ total sugar consumption). It must be noted that the broths fermented by $C$. saccharobutylicum DSM 13864 acquired a gelatinous appearance, probably due to the formation of a polysaccharide, a fact that could explain the low concentration of total free sugars at the end of the fermentation with this strain. According to these results and taking into account both $A B E$ concentrations and sugar consumption, it was decided to select the strain DSM 13864 for the optimisation experiments.

Corn stover hydrolysates have been subjected to $A B E$ fermentation employing several wild strains, such as C. acetobutylicum P262 (Parekh et al., 1988), C. acetobutylicum zzu-02 (Zhang et al., 2018), C. acetobutylicum ATCC 824 (=DSM 792) (Wang and Chen, 2011; Zhang et al., 2014), C. beijerinckii NCIMB 8052 (=CECT 508) (Liu et al., 2017), C. beijerinckii zzu-01 (Zhang et al., 2018), C. beijerinckii P260 (Qureshi et al., 2010; Qureshi et al., 2014) and C. saccharobutylicum DSM 13864 (Xu et al., 2016); or modified strains, like C. acetobutylicum ABE-P 1201 (Cai et al., 2017), C. beijerinckii CC101 (Xue et al., 2016a) or C. beijerinckii NCIMB 4110 (Tang et al., 2017). The selected strain in the present work (DSM 13864), belongs to the species C. saccharobutylicum, which has been reported to cope with mixed agricultural and waste-based substrates (Shaheen et al., 2000).

\subsection{Optimisation of fermentation conditions for non-detoxified corn stover hydrolysates}

The most adequate nutrients and fermentation conditions for C. saccharobutylicum DSM 13864 were evaluated as described in the Appendix (Tables A1-A7). The optimal working conditions, as well as the nutrient concentrations established in the Plackett-Burman and RSM experiments, have been summarised in Table 2 (optimised conditions - O). The calculated optimum answer established that it would be possible to produce $7.56 \mathrm{~g} / \mathrm{L}$ butanol when working at $28{ }^{\circ} \mathrm{C}, \mathrm{pH} 5.42$ and $8.0 \mathrm{~g} / \mathrm{L} \mathrm{CaCO}$. In order to validate the model, this optimal point was experimentally tested by fermenting nondetoxified corn stover hydrolysates under these optimised conditions. The results of model validation yielded a butanol concentration of $5.38 \pm 0.21 \mathrm{~g} / \mathrm{L}$, which is far from the estimated value $(7.56 \mathrm{~g} / \mathrm{L})$. In addition, other fermentation experiments were performed on different days under similar circumstances obtaining variable butanol concentrations in the range of 4.49-6.38 $\mathrm{g} / \mathrm{L}$. This lack of repeatability might be related to the inhospitable nature of corn stover acid hydrolysate for bacteria (Qureshi et al. 2010), which could cause a selective pressure on microorganisms via toxic effects, that would lead to the survival of those organisms with a higher resistance to inhibitors, which may not be the best butanol producers. Even if the same spores batch of a bacterial strain is used in different experiments, not all the individuals are identical and, in addition, can suffer genetic changes during their development and reproduction causing a large amount of phenotypical variability inside this environment. This potential selective pressure generated by the toxic compounds could be faced by applying a detoxification step for this corn stover hydrolysate. In any case, under other circumstances (detoxified hydrolysates; Figure A2) the optimised conditions $(\mathrm{O})$ were proved to be superior to the standard conditions (S) for $C$. saccharobutylicum DSM 13864 and therefore they were maintained for further experiments.

Table 4 shows fermentation performances of non-detoxified corn stover hydrolysates found in literature. The results from the present work are in agreement with other comparable studies employing batch fermentations, where butanol concentrations of $0-6.93 \mathrm{~g} / \mathrm{L}$ were attained. The highest titers had been reported by Zhang et al. (2018), who employed a hydrolysate with a greater initial sugar concentration compared to the present work (52 vs. $40.5 \mathrm{~g} / \mathrm{L}$ ), but they did not report sugar consumption values or butanol yields. This satisfactory result could be due to the selection of the most appropriate strain for 
this specific hydrolysate (C. saccharobutylicum DSM 13864). In addition, the registered sugar consumption of $83 \%$ is notably high, and it is near the values observed in semicontinuous reactors with in situ butanol recovery (Parekh et al., 1988). This fact could be related to the relatively low initial sugar concentration in the broth and to the hypothetical formation of an extracellular polysaccharide by $C$. saccharobutylicum DSM 13864; although other non-polysaccharide forming strains, such as DSM 6423 and DSM 2152, had also shown sugar consumption values above $70 \%$ (Figure 1).

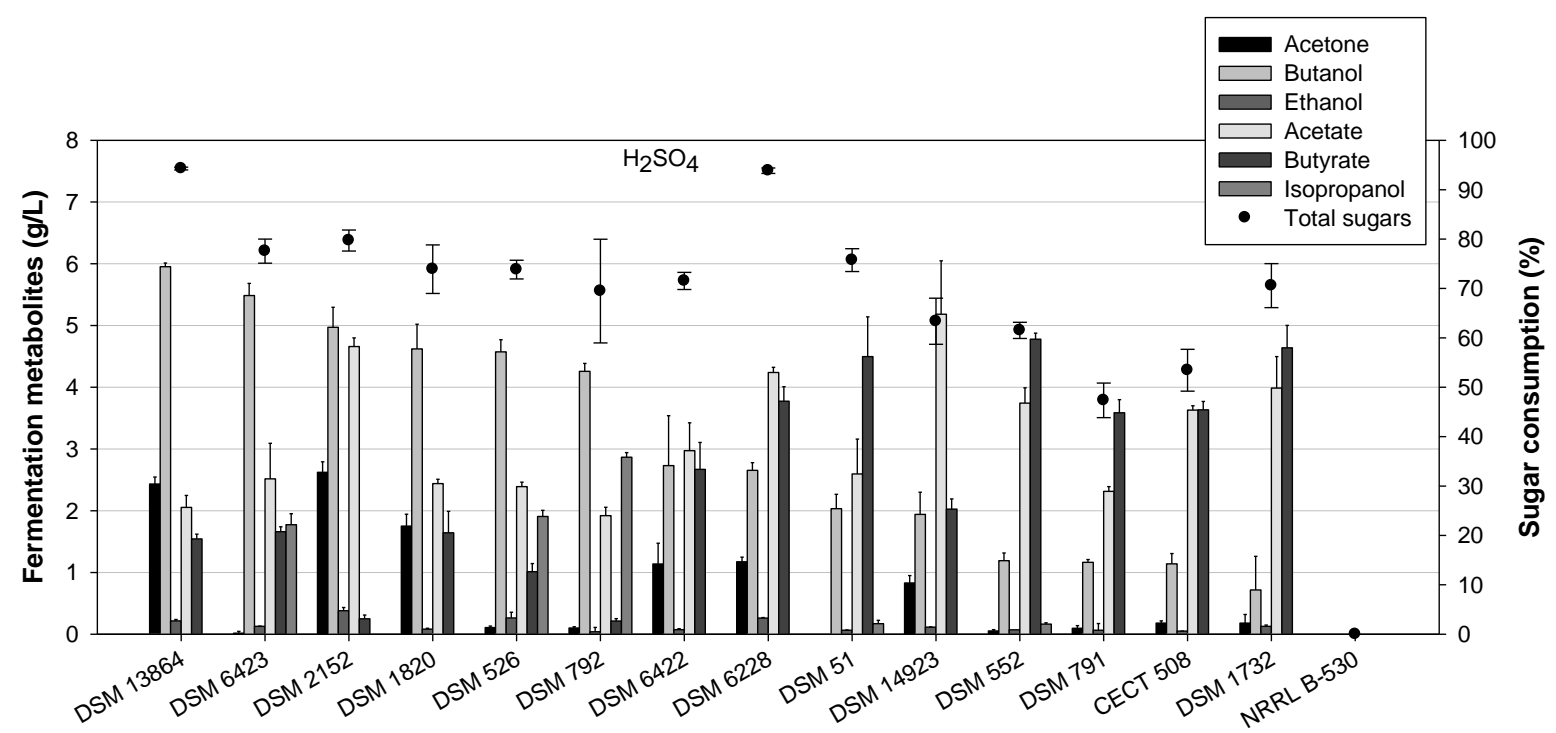

Figure 1. Sugar consumption and $A B E$ parameters for a 96-h fermentation of non-detoxified corn stover hydrolysates (pretreatment $125^{\circ} \mathrm{C}, 5 \mathrm{~min}, 0.89 \% \mathrm{w} / \mathrm{w} \mathrm{H}_{2} \mathrm{SO}_{4}$ ) by several Clostridium strains.

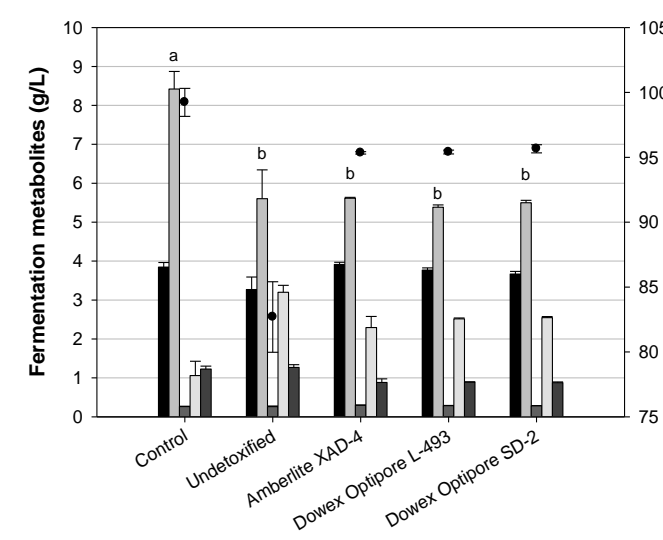

a

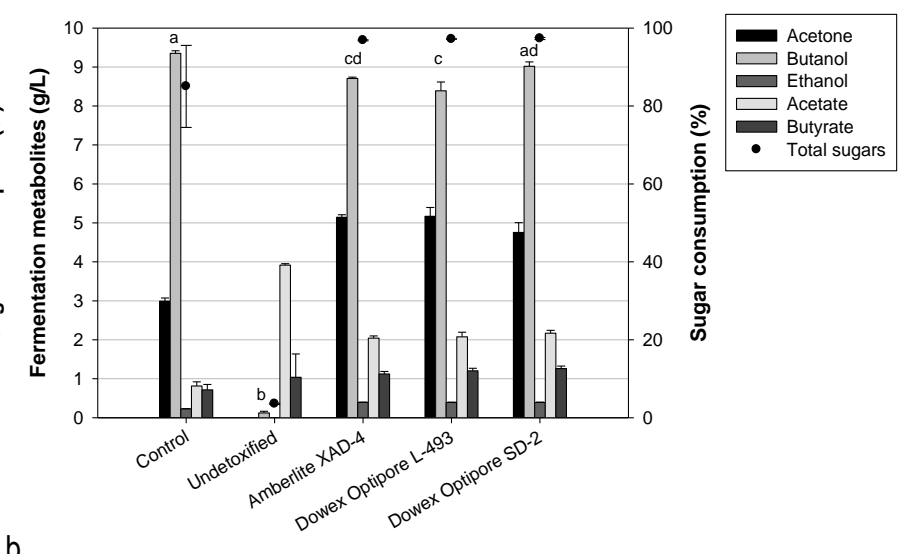

b

Figure 2. Fermentation of corn stover hydrolysates before and after detoxification with three adsorption resins with $C$. saccharobutylicum DSM 13864. Different letters above butanol bars represent statistical differences among samples $(p<0.05)$. a) Pretreatment at $125^{\circ} \mathrm{C}, 0.89 \% \mathrm{H}_{2} \mathrm{SO}_{4} \mathrm{w} / \mathrm{w}, 5 \mathrm{~min}$. The control consisted of an aqueous solution containing $22 \mathrm{~g} / \mathrm{L}$ glucose, 16 $\mathrm{g} / \mathrm{L}$ xylose and nutrients. b) Pretreatment at $160^{\circ} \mathrm{C}, 0.89 \% \mathrm{H}_{2} \mathrm{SO}_{4} \mathrm{w} / \mathrm{w}, 5 \mathrm{~min}$. The control consisted of an aqueous solution containing $31 \mathrm{~g} / \mathrm{L}$ glucose, $22 \mathrm{~g} / \mathrm{L}$ xylose and nutrients. Note: More fermentation parameters are given in Table A8. 
Table 4. Comparison of ABE fermentations from non-detoxified corn stover hydrolysates. Note: In all cases, an enzymatic hydrolysis was performed after physicochemical pretreatment.

\begin{tabular}{|c|c|c|c|c|c|c|c|c|c|}
\hline Pretreatment & Other & $\begin{array}{l}\text { Initial } \\
\text { sugars } \\
\text { (g/L) }\end{array}$ & Strain & $\begin{array}{l}A \\
(g / L)\end{array}$ & $\begin{array}{l}B \\
\text { (g/L) }\end{array}$ & $\begin{array}{l}E \\
(g / L)\end{array}$ & $\begin{array}{l}\text { Sugar } \\
\text { consumption } \\
(\%)\end{array}$ & $\begin{array}{l}t \\
\text { (h) }\end{array}$ & Reference \\
\hline $\begin{array}{l}\text { Steam, } 3 \% \\
\mathrm{SO}_{2} \text {. } \\
\text { Water:solid } \\
2: 1 . \quad 160^{\circ} \mathrm{C} \text {, } \\
30 \mathrm{~min} .\end{array}$ & $\begin{array}{l}\text { Semicontinuous. } \\
\text { In situ recovery } \\
\text { (liquid-liquid). }\end{array}$ & 81 & $\begin{array}{l}\text { C. acetobutylicum } \\
\text { P262 }\end{array}$ & - & 15 & - & 93 & 24 & $\begin{array}{l}\text { Parekh et } \\
\text { al. (1988) }\end{array}$ \\
\hline $\begin{array}{l}\mathrm{H}_{2} \mathrm{SO}_{4} \quad 1 \% \text {, } \\
\text { v/v. } 160^{\circ} \mathrm{C}, \\
20 \text { min. } \sim 8 \% \\
\text { solid. }\end{array}$ & Batch. & 60 & $\begin{array}{l}\text { C. beijerinckii } \\
\text { P260 }\end{array}$ & 0 & 0 & 0 & 0 & - & $\begin{array}{l}\text { Qureshi et } \\
\text { al. (2010) }\end{array}$ \\
\hline $\begin{array}{lr}\mathrm{H}_{2} \mathrm{SO}_{4} & 2 \%, \\
\text { v/v. Steam } \\
\text { explosion } \\
0.7 \quad \mathrm{MPa}, \\
150^{\circ} \mathrm{C}, \quad 15 \\
\text { min. }\end{array}$ & Batch. & 75 & $\begin{array}{l}\text { C. beijerinckii } \\
\text { NCIMB } 8052\end{array}$ & 2.3 & 3.7 & - & 20 & 48 & $\begin{array}{l}\text { Liu et al. } \\
(2017)\end{array}$ \\
\hline $\begin{array}{l}\text { Steam } \\
\text { explosion } \\
1.5 \mathrm{MPa} \text {. }\end{array}$ & Batch. & 52 & $\begin{array}{l}\text { C. acetobutylicum } \\
\text { zzu-02 }\end{array}$ & - & 6.93 & - & - & - & $\begin{array}{l}\text { Zhang et } \\
\text { al. (2018) }\end{array}$ \\
\hline $\begin{array}{l}\text { Steam } \\
\text { explosion } \\
1.5 \mathrm{MPa} \text {. }\end{array}$ & Batch. & 52 & $\begin{array}{l}\text { C. beijerinckii zzu- } \\
01\end{array}$ & - & 5.24 & - & - & - & $\begin{array}{l}\text { Zhang et } \\
\text { al. (2018) }\end{array}$ \\
\hline $\begin{array}{l}\mathrm{H}_{2} \mathrm{SO}_{4} \\
0.89 \%, \quad \text { w/w } \\
(\sim 0.54 \% \\
\text { v/v). } 125^{\circ} \mathrm{C}, 5 \\
\text { min. } \quad 10 \% \\
\text { solid. }\end{array}$ & Batch. & 40.5 & $\begin{array}{l}\text { C. } \\
\text { saccharobutylicum } \\
\text { DSM } 13864\end{array}$ & 2.7 & 5.38 & 0.27 & 83 & 96 & This work \\
\hline $\begin{array}{l}\mathrm{H}_{2} \mathrm{SO}_{4} \\
0.89 \%, \quad \text { w/w } \\
(\sim 0.54 \% \\
\text { v/v). } 160^{\circ} \mathrm{C}, 5 \\
\text { min. } \quad 10 \% \\
\text { solid. }\end{array}$ & Batch. & 47.18 & $\begin{array}{l}\text { C. } \\
\text { saccharobutylicum } \\
\text { DSM } 13864\end{array}$ & 0.0 & 0.12 & 0.0 & 3.6 & 72 & This work \\
\hline
\end{tabular}

\subsection{Detoxification of corn stover hydrolysates}

Due to the presence of inhibitors, corn stover hydrolysate was not readily fermentable, and butanol production did not exceed the threshold of 4-6 $\mathrm{g} / \mathrm{L}$ in spite of strain screening, nutrient optimisation and adjustment of fermentation conditions. Therefore, after physicochemical pretreatment $\left(0.89 \% \mathrm{H}_{2} \mathrm{SO}_{4} \mathrm{w} / \mathrm{w}, 125^{\circ} \mathrm{C}, 5 \mathrm{~min}\right)$ and enzymatic hydrolysis, corn stover hydrolysate was detoxified with three adsorption resins as described in section 2.8. Detoxification results can be found in Table 5 . Most inhibitors were removed from the hydrolysates (especially 5-HMF and phenolic compounds), but sugars were also retained by the resins (14.7-17.8\%), which implies an important loss of sugars for the subsequent fermentation process. These detoxified hydrolysates were fermented during 96 h with C. saccharobutylicum DSM 13864. According to Figure $2 \mathrm{a}$, the detoxification process did not clearly enhance bacterial activity. In fact, butanol production in the best case (5.62 $\pm 0.02 \mathrm{~g} / \mathrm{L}$, with Amberlite ${ }^{\circledR}$ XAD-4) was similar to that of the non-detoxified hydrolysate $(p>$ 
0.05). In spite of the successful removal of inhibitors, $A B E$ concentrations were not improved in a significant way, probably because of the decrease in sugar concentrations caused by the resin treatment $(33.8-35.1 \mathrm{~g} / \mathrm{L}$ initial sugars).

As a consequence, it was checked whether a detoxified hydrolysate with higher sugar concentrations would produce greater $\mathrm{ABE}$ yields. For this experiment, a hydrolysate containing about $50 \mathrm{~g} / \mathrm{L}$ total sugars, obtained with an aqueous solution of $0.89 \% \mathrm{H}_{2} \mathrm{SO}_{4}(\mathrm{w} / \mathrm{w})$ at $160^{\circ} \mathrm{C}$ during $5 \mathrm{~min}$ (Table 3), was chosen and detoxified with the three resins. Inhibitor concentrations were importantly reduced by the resins, while sugar concentrations decreased by 11.9-13.2\% (Table 5). Therefore, fermentations were started with initial sugar concentrations of 43.7-44.4 $\mathrm{g} / \mathrm{L}$, using the optimised nutrients and fermentation conditions $(\mathrm{O})$ described in Table 2. The fermentation was finished after $72 \mathrm{~h}$. The non-detoxified hydrolysate was not fermentable, yielding barely $0.12 \pm 0.04 \mathrm{~g} / \mathrm{L}$ butanol (Figure $2 b)$. On the contrary, detoxified samples obtained butanol concentrations of $8.71 \pm 0.03$ $\mathrm{g} / \mathrm{L}, 8.39 \pm 0.23 \mathrm{~g} / \mathrm{L}$ and $9.02 \pm 0.11 \mathrm{~g} / \mathrm{L}$ for resins Amberlite ${ }^{\circledR}$ XAD-4, Dowex ${ }^{\circledR}$ Optipore ${ }^{\circledR}$ L-493 and Dowex ${ }^{\circledR}$ Optipore ${ }^{\circledR}$ SD-2, respectively. In addition, butanol concentrations recorded for the sample detoxified with Dowex ${ }^{\circledR}$ Optipore ${ }^{\circledR}$ SD-2 were not significantly different $(p>0.05)$ from those of the control, which indicates that any potential inhibitory effects had been eliminated during detoxification. Therefore, the pretreatment at $160{ }^{\circ} \mathrm{C}$ aiming at releasing more sugars was successful for $A B E$ fermentation, provided that a detoxification step is performed. This process implied a clear improvement in butanol production (from $5.38 \pm$ $0.21 \mathrm{~g} / \mathrm{L}$ to $9.02 \pm 0.11 \mathrm{~g} / \mathrm{L}$ butanol) and fermentation time (from $96 \mathrm{~h}$ to $72 \mathrm{~h}$ ) in comparison to the previous values obtained before detoxification (section 3.3). The fermentation of the hydrolysate detoxified with resin Dowex ${ }^{\circledR}$ Optipore ${ }^{\circledR}$ SD-2 obtained $4.75 \pm$ $0.25 \mathrm{~g} / \mathrm{L}$ acetone, $9.02 \pm 0.11 \mathrm{~g} / \mathrm{L}$ butanol, $0.39 \pm$ $0.01 \mathrm{~g} / \mathrm{L}$ ethanol, $2.17 \pm 0.07 \mathrm{~g} / \mathrm{L}$ acetic acid and $1.26 \pm 0.07 \mathrm{~g} / \mathrm{L}$ butyric acid, with a sugar consumption of $97.3 \pm 0.27 \%$, a butanol yield $\mathrm{Y}_{\mathrm{B} / \mathrm{S}}$ of $0.222 \pm 0.003 \mathrm{~g} / \mathrm{g}$ and a butanol productivity $W_{B}$ of $0.125 \pm 0.002 \mathrm{~g} /(\mathrm{L} \cdot \mathrm{h})$.
The three adsorption resins used in the present study had been previously assessed for the adsorption of phenolic compounds (Lin and Juang, 2009), for the in situ recovery of butanol from fermentation broths (Xue et al., 2016c) and for the detoxification of various lignocellulosic hydrolysates, but they had never been used for the detoxification of corn stover hydrolysates. Gao and Rehman (2016) used the resin Dowex Optipore L-493 to simultaneously adsorb inhibitors and butanol during the fermentation of an acid hydrolysate of Phragmites australis. The resin adsorbed $2.98 \%$ glucose, $4.85 \%$ xylose, 7.84\% acetic acid, 33.3\% 5-HMF, 77.8\% furfural and $95.1 \%$ total phenolic compounds. Shukor et al. (2014) detoxified the acid hydrolysate of palm kernel cake with Amberlite XAD-4 and observed a reduction of $50 \%$ furfural and $77 \% 5-\mathrm{HMF}$, without losses of glucose or mannose. On the other hand, Ezeji et al. (2007) compared overliming and Amberlite XAD-4 as detoxification methods for corn fiber hydrolysates and concluded that overliming was superior, although the resin removed $60-80 \%$ furfural, 5-HMF and ferulic acid. Sugar losses were $2.99 \%$ for overliming and $10.72 \%$ for the resin. Weil et al. (2002) subjected a corn fiber hydrolysate to detoxification with resins Amberlite XAD-4 and XAD-7 and were able to remove $96 \%$ furfural. Our results are in agreement with the reported removal ranges in the case of furfural, 5-HMF and phenolic compounds, and are slightly higher in the case of acetic acid. However, sugar losses in the present study (12-18\%) are clearly higher than those mentioned in literature (0-11\%).

Table 6 presents a summary of fermentation performances using detoxified corn stover hydrolysates found in literature. The most common detoxification techniques for this substrate are dilution with water, overliming, washing of the solid biomass after physicochemical pretreatment, alkaline peroxide and adsorption onto activated charcoal. To the best of our knowledge, this is the first time that polymeric resins are employed for the detoxification of corn stover hydrolysate. Butanol production in the present work $(9.02 \mathrm{~g} / \mathrm{L})$ is similar or higher than that of other papers (0.36$14.5 \mathrm{~g} / \mathrm{L}$ ) and it is in the range of those experiments where fermentations were started with sugar concentrations below $45 \mathrm{~g} / \mathrm{L}$ (7.1-11.5 
$\mathrm{g} / \mathrm{L}$ butanol). Steam explosion, dilute sulfuric acid, dilute $\mathrm{NaOH}$, organosolv and deep eutectic solvents have been employed as physicochemical pretreatments for corn stover hydrolysis (Table 4 and Table 6). Dilute sulfuric acid pretreatment is frequent at an industrial scale (Baral and Shah, 2014). The concentration of $\mathrm{H}_{2} \mathrm{SO}_{4}$ used in the present work $(0.89 \% \mathrm{w} / \mathrm{w}$ or $\sim 0.54 \% \mathrm{v} / \mathrm{v}$ ) is clearly below the values of $1-2 \%$ $\mathrm{v} / \mathrm{v}$ reported in literature (Table 4 and Table 6), which constitutes an advantage from both an economic and environmental points of view. Moreover, the short pretreatment times (5 min) proposed would require less energy consumption.

Current detoxification methods include overliming, evaporation, adsorption (onto resins or activated charcoal) or biological methods (use of peroxidases and laccases) (Baral and Shah, 2014). Adsorption resins have been regarded as an expensive detoxification method (Mussatto and Roberto, 2004). However, the possibility of immobilising resins inside columns to perform continuous processes and the recyclability of these materials by regeneration make them attractive for industrial applications. In addition, other detoxification methods employing alkali addition or activated carbon can reduce acetic acid, furfural and phenolic compounds concentration, but they can also induce salt formation, which can be detrimental for Clostridium species (Baral and Shah, 2014). Furthermore, detoxification techniques by washing the solid biomass before the enzymatic hydroysis imply the loss of the pentoses and other hemicellulosic sugars released during the physicochemical pretreatment.

Moreover, in comparison to detoxification by washing (Table 4, Table 6), resins could entail water savings. Sainio et al. (2011) proved that the resin Amberlite XAD-16 (whose composition is similar to that of XAD-4) could be regenerated with a $50 \%$ ethanol aqueous solution in order to remove fermentation inhibitors such as furfural. Weil et al. (2002) proposed the use of adsorption resins as detoxification method in continuous processing systems and they confirmed the regenerability of the resin Amberlite XAD-4 with ethanol.

Table 5. Concentrations of total sugars and inhibitors in corn stover hydrolysates after detoxification with three adsorption resins. Percentage changes are shown between brackets.

\begin{tabular}{|c|c|c|c|c|c|c|c|}
\hline & $\begin{array}{c}\text { Total } \\
\text { sugars } \\
(\mathrm{g} / \mathrm{L})\end{array}$ & $\begin{array}{l}\text { Formic } \\
\text { acid (g/L) }\end{array}$ & $\begin{array}{l}\text { Acetic acid } \\
\text { (g/L) }\end{array}$ & $\begin{array}{l}\text { Levulinic } \\
\text { acid }(g / L)\end{array}$ & 5-HMF (g/L) & $\begin{array}{c}\text { Furfural } \\
(\mathrm{g} / \mathrm{L})\end{array}$ & $\begin{array}{c}\text { Phenolic } \\
\text { compounds } \\
(\mathrm{g} / \mathrm{L})\end{array}$ \\
\hline \multicolumn{8}{|c|}{ Pretreatment at $125^{\circ} \mathrm{C}, 0.89 \% \mathrm{H}_{2} \mathrm{SO}_{4} \mathrm{w} / \mathrm{w}, 5 \mathrm{~min}$} \\
\hline Undetoxified & 41.15 & 0.07 & 2.57 & $\leq 0.02$ & 0.10 & 0.03 & 1.17 \\
\hline Amberlite $®$ XAD-4 & $\begin{array}{c}35.09 \\
(-14.7 \%) \\
\end{array}$ & $\begin{array}{l}0.07 \\
(0 \%)\end{array}$ & $\begin{array}{c}2.10 \\
(-18.3 \%) \\
\end{array}$ & $\begin{array}{c}\leq 0.02 \\
(0 \%)\end{array}$ & $\begin{array}{c}0.02 \\
(-80.0 \%) \\
\end{array}$ & $\begin{array}{c}\leq 0.02 \\
(-33.3 \%)\end{array}$ & $\begin{array}{c}0.19 \\
(-83.8 \%) \\
\end{array}$ \\
\hline Dowex® Optipore ${ }^{\circledR}$ L-493 & $\begin{array}{c}33.81 \\
(-17.8 \%)\end{array}$ & $\begin{array}{c}0.06 \\
(-14.3 \%)\end{array}$ & $\begin{array}{c}1.78 \\
(-30.7 \%)\end{array}$ & $\begin{array}{c}\leq 0.02 \\
(0 \%)\end{array}$ & $\begin{array}{c}0.02 \\
(-80.0 \%)\end{array}$ & $\begin{array}{c}\leq 0.02 \\
(-33.3 \%)\end{array}$ & $\begin{array}{c}0.05 \\
(-95.7 \%)\end{array}$ \\
\hline Dowex® Optipore $®$ SD-2 & $\begin{array}{c}34.00 \\
(-17.4 \%) \\
\end{array}$ & $\begin{array}{l}0.07 \\
(0 \%) \\
\end{array}$ & $\begin{array}{c}2.06 \\
(-19.8 \%) \\
\end{array}$ & $\begin{array}{c}\leq 0.02 \\
(0 \%)\end{array}$ & $\begin{array}{c}0.02 \\
(-80.0 \%)\end{array}$ & $\begin{array}{c}\leq 0.02 \\
(-33.3 \%)\end{array}$ & $\begin{array}{c}0.01 \\
(-99.2 \%)\end{array}$ \\
\hline \multicolumn{8}{|c|}{ Pretreatment at $160^{\circ} \mathrm{C}, 0.89 \% \mathrm{H}_{2} \mathrm{SO}_{4} \mathrm{w} / \mathrm{w}, 5 \mathrm{~min}$} \\
\hline Undetoxified & 50.39 & 0.10 & 3.61 & 0.08 & 0.36 & 0.78 & 1.43 \\
\hline Amberlite $₫ \mathrm{XAD}-4$ & $\begin{array}{c}43.72 \\
(-13.2 \%) \\
\end{array}$ & $\begin{array}{l}0.10 \\
(0 \%)\end{array}$ & $\begin{array}{c}2.95 \\
(-18.3 \%) \\
\end{array}$ & $\begin{array}{c}\leq 0.02 \\
(-75.0 \%)\end{array}$ & $\begin{array}{c}\leq 0.02 \\
(-94.4 \%)\end{array}$ & $\begin{array}{c}\leq 0.02 \\
(-97.0 \%)\end{array}$ & $\begin{array}{c}0.19 \\
(-86.7 \%) \\
\end{array}$ \\
\hline Dowex® Optipore $® \mathrm{~L}-493$ & $\begin{array}{c}44.39 \\
(-11.9 \%) \\
\end{array}$ & $\begin{array}{c}0.11 \\
(10.0 \%) \\
\end{array}$ & $\begin{array}{c}2.57 \\
(-28.8 \%) \\
\end{array}$ & $\begin{array}{c}\leq 0.02 \\
(-75.0 \%)\end{array}$ & $\begin{array}{c}\leq 0.02 \\
(-94.4 \%)\end{array}$ & $\begin{array}{c}\leq 0.02 \\
(-97.0 \%)\end{array}$ & $\begin{array}{c}0.10 \\
(-93.0 \%)\end{array}$ \\
\hline Dowex® Optipore $®$ SD-2 & $\begin{array}{c}44.10 \\
(-12.5 \%) \\
\end{array}$ & $\begin{array}{c}0.11 \\
(10.0 \%) \\
\end{array}$ & $\begin{array}{c}2.93 \\
(-18.8 \%) \\
\end{array}$ & $\begin{array}{c}\leq 0.02 \\
(-75.0 \%)\end{array}$ & $\begin{array}{c}\leq 0.02 \\
(-94.4 \%)\end{array}$ & $\begin{array}{c}\leq 0.02 \\
(-97.0 \%)\end{array}$ & $\begin{array}{c}0.06 \\
(-95.8 \%) \\
\end{array}$ \\
\hline
\end{tabular}


Therefore, if adsorption resins were used for inhibitor removal at industrial scale in $\mathrm{ABE}$ biorefineries, they could be regenerated by washing them with the same solvents recovered from the fermentation broth (acetone or ethanol), thus obtaining a solution rich in furans and phenolic compounds which could also have commercial value.

Table 6. Comparison of ABE fermentations from corn stover hydrolysates detoxified with several methods. Note: In all cases, an enzymatic hydrolysis was performed after physicochemical pretreatment.

\begin{tabular}{|c|c|c|c|c|c|c|c|c|c|c|}
\hline Pretreatment & Detoxification & Other & \begin{tabular}{|l|} 
Initial \\
sugars \\
(g/L)
\end{tabular} & Strain & $A(g / L)$ & $B(g / L)$ & $E(g / L)$ & \begin{tabular}{|l|} 
Sugar \\
consump. \\
$(\%)$
\end{tabular} & $t(h)$ & Reference \\
\hline \multirow{6}{*}{$\begin{array}{lr}\mathrm{H}_{2} \mathrm{SO}_{4} & 1 \%, \\
\text { v/v. } 160^{\circ} \mathrm{C}, & 20 \\
\text { min. } \sim 8 \% & \text { solid. }\end{array}$} & \begin{tabular}{|l|} 
Dilution with water \\
$1: 1$
\end{tabular} & Batch. & 60 & C. beijerinckii P260 & 4.7 & 10.4 & 0.9 & 62.06 & 96 & Qureshi et al. (2010) \\
\hline & $\begin{array}{|ll|}\text { Dilution } & \text { with wheat } \\
\text { straw } & \text { hydrolysate } \\
1: 1 & \\
\end{array}$ & Batch. & 59.3 & C. beijerinckii P260 & 5.1 & 12.3 & 0.64 & 69.98 & 84 & Qureshi et al. (2010) \\
\hline & Overliming & Batch. & 60.3 & C. beijerinckii P260 & 8 & 14.5 & 3.77 & 99.17 & 85 & Qureshi et al. (2010) \\
\hline & Overliming & Batch. & 39 & C. beijerinckii P260 & 5.55 & 6.04 & 0.89 & 88.87 & 96 & Qureshi et al. (2014) \\
\hline & Overliming & SSF & 39 & C. beijerinckii P260 & 4.82 & 8.98 & 0.4 & 86.59 & 73 & Qureshi et al. (2014) \\
\hline & Overliming & $\begin{array}{l}\text { SSF and } \\
\text { recovery }\end{array}$ & 39 & C. beijerinckii P260 & 8.1 & 11.58 & 1.11 & 100 & 60 & Qureshi et al. (2014) \\
\hline $\begin{array}{|lr|}\mathrm{H}_{2} \mathrm{SO}_{4} & 2 \% \\
\mathrm{v} / \mathrm{v} . \mathrm{Steam} & \\
\text { explosion } & 0.7 \\
\mathrm{MPa}, 150^{\circ} \mathrm{C}, 15 \\
\text { min. }\end{array}$ & Overliming & Batch. & 75 & $\begin{array}{l}\text { C. beijerinckii NCIMB } \\
8052\end{array}$ & 7.8 & 10.4 & 0.41 & 71.3 & 48 & Liu et al. (2017) \\
\hline \multirow{3}{*}{$\begin{array}{l}\text { Steam } \\
\text { explosion, } 1.1 \\
\mathrm{MPa}, 4 \mathrm{~min} .\end{array}$} & Washing. & Batch. & 53.52 & $\begin{array}{l}\text { C. acetobutylicum } \\
\text { ATCC } 824\end{array}$ & 1.15 & 0.36 & 2.20 & 52 & 72 & $\begin{array}{l}\text { Wang and Chen } \\
(2011)\end{array}$ \\
\hline & $\begin{array}{|lr|}\text { Alkaline reroxide, } & \text { per } \\
4 \% \mathrm{H}_{2} \mathrm{O}_{2}, 1 \% \mathrm{NaOH}, \\
24 \text { h. } 10 \% & \text { solid } \\
\text { biomass. }\end{array}$ & Batch & 45 & $\begin{array}{l}\text { C. acetobutylicum } \\
\text { ATCC } 824\end{array}$ & -2.7 & 8.3 & -1.2 & 95.78 & 72 & $\begin{array}{l}\text { Wang and Chen } \\
(2011)\end{array}$ \\
\hline & \begin{tabular}{|l|} 
Activated charcoal \\
$7.5 \% \quad(\mathrm{w} / \mathrm{v}), \quad 30^{\circ} \mathrm{C}$, \\
$150 \mathrm{rpm}, 12 \mathrm{~h}$.
\end{tabular} & Batch. & 49 & $\begin{array}{l}\text { C. acetobutylicum } \\
\text { ATCC } 824\end{array}$ & -2.5 & 8.4 & $\sim 1.5$ & 91.43 & 72 & $\begin{array}{l}\text { Wang and Chen } \\
(2011)\end{array}$ \\
\hline $\begin{array}{ll}\text { Steam } \\
\text { explosion } \quad 1.5 \\
\mathrm{MPa} \text {. }\end{array}$ & Washing. & Batch. & 57.5 & $\begin{array}{l}\text { C. acetobutylicum } \\
\text { zzu-02 }\end{array}$ & 4.14 & 9.88 & 1.80 & 97.74 & 70 & Zhang et al. (2018) \\
\hline $\begin{array}{l}\mathrm{NaOH} r 2 \%, \\
121^{\circ} \mathrm{C}, 30 \mathrm{~min} .\end{array}$ & Washing. & Batch. & 71.3 & $\begin{array}{l}\text { C. beijerinckii CC101 } \\
\text { (adaptative mutant) }\end{array}$ & 7.5 & 11.2 & 1.1 & 68 & 57 & Xue et al. (2016a) \\
\hline $\begin{array}{l}\text { Deep eutectic } \\
\text { solvents, } \\
130^{\circ} \mathrm{C}, 2 \mathrm{~h} .\end{array}$ & Washing. & Batch. & 48.2 & \begin{tabular}{|l} 
C. \\
saccharobutylicum \\
DSM 13864
\end{tabular} & -1.2 & 5.63 & 0.3 & 70.54 & 48 & Xu et al. (2016) \\
\hline \begin{tabular}{|l|} 
Twin-screw \\
extrusion, \\
$\mathrm{NaOH} \quad 8 \%$, \\
$99^{\circ} \mathrm{C}, 1$ h. $33 \%$ \\
solid. \\
\end{tabular} & Washing. & Batch. & 42.4 & $\begin{array}{l}\text { C. acetobutylicum } \\
\text { ATCC } 824\end{array}$ & -2.7 & 7.1 & -1.2 & 92.7 & 72 & Zhang et al. (2014) \\
\hline 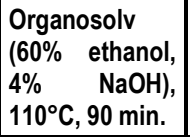 & Washing. & Batch. & 30 & $\begin{array}{l}\text { C. beijerinckii NCIMB } \\
4110 \text { (mutant) }\end{array}$ & - & 9.9 & - & -95 & 72 & Tang et al. (2017) \\
\hline $\begin{array}{|lr|}\mathrm{H}_{2} \mathrm{SO}_{4} & 0.89 \% \\
\mathrm{w} / \mathrm{w} & (\sim 0.54 \% \\
\mathrm{v} / \mathrm{v}) .125^{\circ} \mathrm{C}, \quad 5 \\
\text { min. } 10 \% \text { solid. }\end{array}$ & $\begin{array}{l}\text { Resin } \quad \text { Dowex } \\
\text { Optipore } ₫ \text { SD-2 }\end{array}$ & Batch. & 37.9 & $\begin{array}{l}\text { C. } \\
\text { saccharobutylicum } \\
\text { DSM } 13864\end{array}$ & 3.70 & 5.58 & 0.28 & 95.66 & 96 & This work \\
\hline $\begin{array}{lr}\mathrm{H}_{2} \mathrm{SO}_{4} & 0.89 \% \\
\text { w/w } & (\sim 0.54 \% \\
\mathrm{v} / \mathrm{v}) .160^{\circ} \mathrm{C}, \quad 5 \\
\text { min. } 10 \% & \text { solid. }\end{array}$ & $\begin{array}{ll}\text { Resin } & \text { Dowex } \\
\text { Optipore } ₫ & \text { SD-2 }\end{array}$ & Batch. & 41.7 & $\begin{array}{l}\text { C. } \\
\text { saccharobutylicum } \\
\text { DSM } 13864\end{array}$ & 4.75 & 9.02 & 0.39 & 97.33 & 72 & This work \\
\hline
\end{tabular}




\subsection{Two-stage gas stripping of fermentation}

\section{broths}

The detoxified hydrolysate was fermented, and the fermentation broth was subjected to a twostage gas stripping process. During the first stage of the gas stripping, butanol concentration in the fermentation broth decreased from 9.02 $\mathrm{g} / \mathrm{L}$ to $2.07 \mathrm{~g} / \mathrm{L}$ in $5 \mathrm{~h}$, and a condensate containing $169.26 \mathrm{~g} / \mathrm{L}$ butanol was collected (Table 7 ). This implies solvent recoveries ( $\eta$ ) of $33.22 \%$ for acetone, $67.70 \%$ for butanol and $38.98 \%$ for ethanol, and selectivity factors $(\alpha)$ of 9.61 for acetone, 22.38 for butanol and 10.85 for ethanol. Gas stripping rates were $0.58 \mathrm{~g} /(\mathrm{L} \cdot \mathrm{h})$ for acetone, $1.39 \mathrm{~g} /(\mathrm{L} \cdot \mathrm{h})$ for butanol, $0.03 \mathrm{~g} /(\mathrm{L} \cdot \mathrm{h})$ for ethanol and $2.00 \mathrm{~g} /(\mathrm{L} \cdot \mathrm{h})$ for $\mathrm{ABE}$. These results are in the upper range of previously reported values for gas stripping. Typical condensates of integrated fed-batch gas stripping processes contain $20-120 \mathrm{~g} / \mathrm{L}$ acetone, $17-113 \mathrm{~g} / \mathrm{L}$ butanol and 7-21 g/L ethanol (Cai et al., 2016; Xue et al., 2016b); with selectivity values of 0.45-30.5 for butanol and 4-30.5 for $A B E$; and gas stripping $A B E$ rates of $0.02-1.34 \mathrm{~g} /(\mathrm{L} \cdot \mathrm{h})$ (Qureshi and Blaschek, 2001; Abdehagh et al., 2014; Xue et al., 2016b). The gas stripping process was successful in spite of the presence of an antifoaming agent, which is known to reduce the system performance (Ezeji et al., 2005). The relatively high butanol concentration in this condensate, notably above butanol solubility in water (7.4 $\mathrm{g} / 100 \mathrm{~g}$ at $298 \mathrm{~K}$; Barton, 1984), resulted in the spontaneous separation of an aqueous and an organic phase. The organic phase had a butanol concentration of $425.35 \mathrm{~g} / \mathrm{L}$. The aqueous phase, with a butanol concentration of $88.70 \mathrm{~g} / \mathrm{L}$, was collected and subjected to a second gas stripping stage.
The second stage of the gas stripping caused a decrease in butanol concentration in the feed solution from $88.70 \mathrm{~g} / \mathrm{L}$ to $1.60 \mathrm{~g} / \mathrm{L}$ in $1 \mathrm{~h}$. In this case, a condensate containing $263.29 \mathrm{~g} / \mathrm{L}$ butanol was collected (Table 8 ). The recorded solvent recoveries $(\eta)$ were $45.81 \%$ for acetone, $73.38 \%$ for butanol and $70.01 \%$ for ethanol. In this second gas stripping step, selectivity factors $(\alpha)$ were lower than in the first stage, since solvent concentrations in the initial feed solution were much higher at the beginning of the second stripping. Thus, selectivity values $(\alpha)$ of 1.94 for acetone, 3.67 for butanol and 2.86 for ethanol were attained. Gas stripping rates during this second stripping stage were $46.9 \mathrm{~g} /(\mathrm{L} \cdot \mathrm{h})$ for acetone, $87.1 \mathrm{~g} /(\mathrm{L} \cdot \mathrm{h})$ for butanol, $3.79 \mathrm{~g} /(\mathrm{L} \cdot \mathrm{h})$ for ethanol and $27.6 \mathrm{~g} /(\mathrm{L} \cdot \mathrm{h})$ for $\mathrm{ABE}$. It has been reported that condensates of two-stage gas stripping processes contain 119-198 g/L acetone, 337-451 $\mathrm{g} / \mathrm{L}$ butanol and 21-23 g/L ethanol (Cai et al., 2016). Once more, the condensate spontaneously separated in two phases. The aqueous phase contained $129.67 \mathrm{~g} / \mathrm{L}$ butanol, a value which is above its solubility in water, but this fact could be explained by the presence of $99.54 \mathrm{~g} / \mathrm{L}$ acetone in this aqueous phase, which could have favoured butanol solubility (Xue et al., 2013a). On the other hand, the organic phase contained $417.71 \mathrm{~g} / \mathrm{L}$ butanol, which is a high value similar to that obtained in the organic phase of the first stripping stage.

Figure 3 summarises butanol fate during the different steps of the gas stripping process. Total mass recoveries (sum of organic phase 1, organic phase 2 and aqueous phase 2) reached 19.91\% acetone, $60.28 \%$ butanol and $30.37 \%$ ethanol.

Table 7. Performance indicators of the first gas stripping stage for the fermented detoxified corn stover hydrolysate.

\begin{tabular}{|l|l|l|l|l|l|l|l|}
\hline & & $\begin{array}{l}\text { Volume } \\
(\mathbf{m L})\end{array}$ & $\begin{array}{l}\text { Acetone } \\
(\mathbf{g} / \mathbf{L})\end{array}$ & $\begin{array}{l}\text { Butanol } \\
(\mathbf{g} / \mathbf{L})\end{array}$ & $\begin{array}{l}\text { Ethanol } \\
(\mathbf{g} / \mathbf{L})\end{array}$ & $\begin{array}{l}\text { Acetic } \\
\text { acid } \\
(\mathbf{g} / \mathbf{L})\end{array}$ & $\begin{array}{l}\text { Butyric } \\
\text { acid } \\
(\mathbf{g} / \mathbf{L})\end{array}$ \\
\hline \multirow{2}{*}{$\begin{array}{l}\text { Fermentation } \\
\text { broth }\end{array}$} & Initial & 3243 & 5.02 & 9.02 & 0.42 & 1.61 & 0.95 \\
\cline { 2 - 8 } & Final & 3126 & 2.11 & 2.07 & 0.28 & 1.10 & 0.75 \\
\hline \multirow{3}{*}{ Condensate } & Mixture & 117 & 46.26 & 169.26 & 4.53 & $<0.05$ & $<0.05$ \\
\cline { 2 - 8 } & $\begin{array}{l}\text { Aqueous } \\
\text { phase }\end{array}$ & 89 & 48.87 & 88.70 & 4.65 & $<0.05$ & $<0.05$ \\
\cline { 2 - 8 } & $\begin{array}{l}\text { Organic } \\
\text { phase }\end{array}$ & 28 & 37.96 & 425.35 & 4.17 & $<0.05$ & $<0.05$ \\
\hline
\end{tabular}


Table 8. Performance indicators of the second gas stripping stage applied to the aqueous phase from the first gas stripping stage.

\begin{tabular}{|l|l|l|l|l|l|l|l|}
\hline & & $\begin{array}{l}\text { Volume } \\
(\mathbf{m l})\end{array}$ & $\begin{array}{l}\text { Acetone } \\
(\mathbf{g} / \mathbf{L})\end{array}$ & $\begin{array}{l}\text { Butanol } \\
(\mathbf{g} / \mathbf{L})\end{array}$ & $\begin{array}{l}\text { Ethanol } \\
(\mathbf{g} / \mathbf{L})\end{array}$ & $\begin{array}{l}\text { Acetic } \\
\text { acid } \\
(\mathbf{g} / \mathbf{L})\end{array}$ & $\begin{array}{l}\text { Butyric } \\
\text { acid } \\
(\mathbf{g} / \mathbf{L})\end{array}$ \\
\hline $\begin{array}{l}\text { Aqueous phase } \\
\text { from the } \\
\text { stripping }\end{array}$ & Initial & 89 & 48.87 & 88.70 & 4.65 & $<0.05$ & $<0.05$ \\
\hline Condensate & Final & 67 & 2.01 & 1.60 & 0.86 & $<0.05$ & $<0.05$ \\
\cline { 2 - 8 } & Mixture & 22 & 90.57 & 263.29 & 13.17 & $<0.05$ & $<0.05$ \\
\cline { 2 - 8 } & $\begin{array}{l}\text { Aqueous } \\
\text { phase }\end{array}$ & 12 & 99.54 & 129.67 & 13.19 & $<0.05$ & $<0.05$ \\
\cline { 2 - 8 } & $\begin{array}{l}\text { Organic } \\
\text { phase }\end{array}$ & 10 & 98.59 & 417.71 & 13.88 & $<0.05$ & $<0.05$ \\
\hline
\end{tabular}

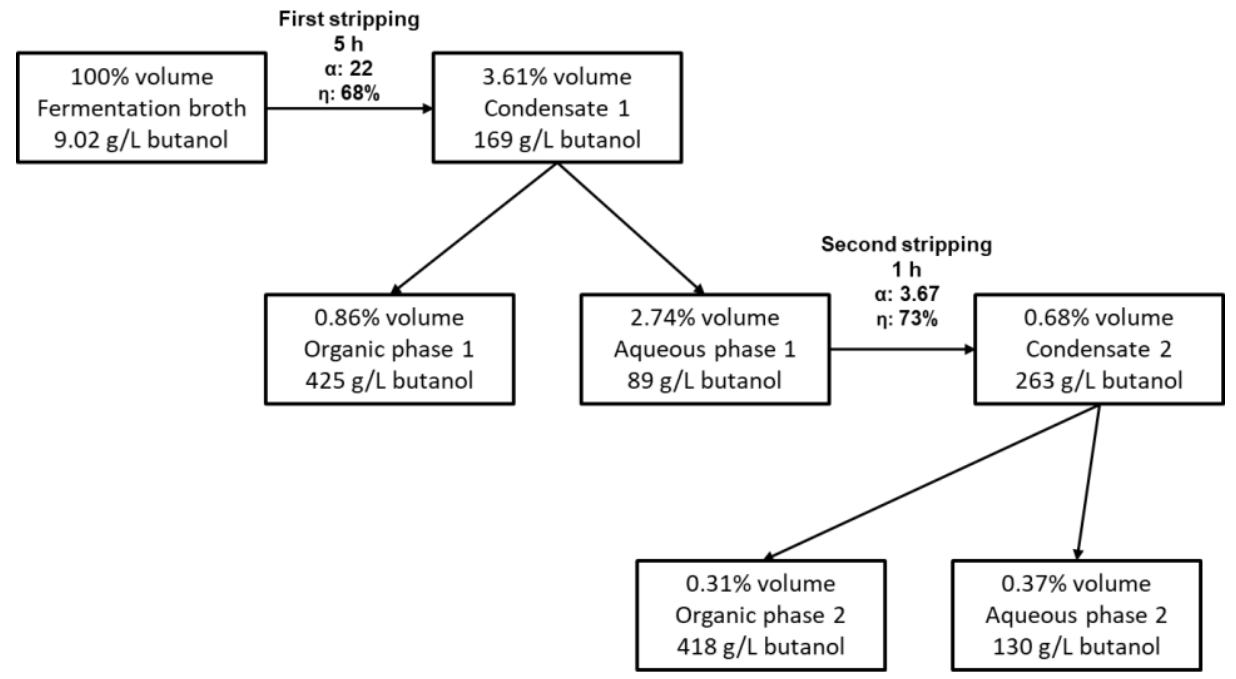

Figure 3. Butanol recovery during the two-stage gas stripping process.

\section{Conclusions}

It is possible to pretreat corn stover by employing low $\mathrm{H}_{2} \mathrm{SO}_{4}$ concentrations $(0.89 \%$ $\mathrm{w} / \mathrm{w}$ ) and yet release about $75 \%$ of its constitutive carbohydrates after enzymatic hydrolysis. However, high temperatures $\left(160{ }^{\circ} \mathrm{C}\right)$ are necessary to guarantee an efficient pretreatment. Due to the presence of fermentation inhibitors in the hydrolysate, a correct strain choice and a detoxification step are essential to carry out a successful $A B E$ fermentation. Despite the fact that in this study one of the highest butanol values has been reported without the necessity of using genetically improved bacterial strains, it could be interesting to test the whole butanol production workflow proposed in this paper with some hyerproducing solventogenic strain previously described, for instance $C$. beijerinckii P260. The use of polymeric adsorption resins immobilised in columns for the detoxification is an attractive alternative, since they may be regenerated and reused by washing them with organic solvents (ethanol, acetone); which could imply the simultaneous recovery of retained phenolic compounds and furans. The present method (including pretreatment, detoxification and fermentation) enabled the production of $43.9 \mathrm{~g}$ acetone/kg corn stover, $83.4 \mathrm{~g}$ butanol/kg corn stover and $3.61 \mathrm{~g}$ ethanol/ $\mathrm{kg}$ corn stover. These solvents could be recovered from the fermentation broth by two-stage gas stripping, producing condensates with 46-91 g/L acetone, 169-263 g/L butanol and 4.5-13.2 g/L ethanol, which separated spontaneously into an aqueous and an organic phase, the latter containing 38- 
$99 \mathrm{~g} / \mathrm{L}$ acetone, 418-425 $\mathrm{g} / \mathrm{L}$ butanol and 4.2$13.9 \mathrm{~g} / \mathrm{L}$ ethanol.

\section{Acknowledgements}

The authors thank Novozymes China for kindly providing samples of their enzymes. Authors thank R. Antón del Río, N. del Castillo Ferreras and G. Sarmiento Martínez for their technical help.

\section{Funding}

The present work has been performed as part of the H2020-WASTE-2015-two-stage Agrocycle project (Sustainable techno-economic solutions for the agricultural value chain. GA - 690142), funded by the European Union's Horizon 2020 Research and Innovation Programme. MH-V is supported by a postdoctoral contract (DOCINIA, grant number DOC 2013-010) funded by the Spanish National Institute for Agricultural and Food Research and Technology (INIA) and the European Social Fund.

\section{References}

Abdehagh, N., Tezel, F.H., Thibault, J., 2014. Separation techniques in butanol production: Challenges and developments. Biomass Bioenerg. 60, 222-246. https://doi.org/10.1016/j.biombioe.2013.10.003.

Baral, N.R., Shah, A., 2014. Microbial inhibitors: formation and effects on acetone-butanol-ethanol fermentation of lignocellulosic biomass. Appl. Microbiol. Biot. 98, 9151-9172. https://doi.org/10.1007/s00253-014-6106-8.

Baral, N.R., Quiroz-Arita, C., Bradley, T.H., 2017. Uncertainties in corn stover feedstock supply logistics cost and life-cycle greenhouse gas emissions for butanol production. Appl. Energ. 208, 1343-1356. https://doi.org/10.1016/j.apenergy.2017.09.020.

Baral, N.R., Shah, A., 2017. Comparative technoeconomic analysis of steam explosion, dilute sulphuric acid, ammonia fiber explosion and biological pretreatments of corn stover. Bioresource Technol. 232, 331-343. https://doi.org/10.1016/j.biortech.2017.02.068.

Barton, A.F.M. (Ed.), 1984. IUPAC Solubility Data Series, Volume 15, Alcohols with Water. Pergamon Press Ltd., Oxford.

Cai, D., Chen, H., Chen, C., Hu, S., Wang, Y., Chang, Z., Miao, Q., Qin, P., Wang, Z., Wang, J., Tan, T., 2016. Gas stripping-pervaporation hybrid process for energy-saving product recovery from acetonebutanol-ethanol (ABE) fermentation broth. Chem. Eng. J. 287, 1-10. https://doi.org/10.1016/j.cej.2015.11.024.
Cai, D., Chen, C., Zhang, C., Wang, Y., Wen, H., Qin, P., 2017. Fed-batch fermentation with intermittent gas stripping using immobilized Clostridium acetobutylicum for biobutanol production from corn stover bagasse hydrolysate. Biochem. Eng. J. 125 , 18-22. http://dx.doi.org/10.1016/j.bej.2017.05.006

de Carvalho, W., Canilha, L., Mussatto, S.I., Dragone, G., Morales, M.L.V., Solenzal, A.I.N., 2004. Detoxification of sugarcane bagasse hemicellulosic hydrolysate with ion-exchange resins for xylitol production by calcium alginate-entrapped cells. J. Chem. Technol. Biotechnol. 79, 863-868. https://doi.org/10.1002/jctb.1061.

Díez-Antolínez, R., Hijosa-Valsero, M., PaniaguaGarcía, A.l., Gómez, X., 2016. Effect of nutrient supplementation on biobutanol production from cheese whey by ABE (Acetone-Butanol-Ethanol) fermentation. Chem. Engineer. Trans. 49, 217-222. https://doi.org/10.3303/CET1649037.

Díez-Antolínez, R., Hijosa-Valsero, M., PaniaguaGarcía, A.I., Gómez, X., 2018. In situ two-stage gas stripping for the recovery of butanol from acetone-butanol-ethanol (ABE) fermentation broths. Chem. Engineer. Trans. 64, 37-42. https://doi.org/10.3303/CET1864007.

Ezeji, T.C., Karcher, P.M., Qureshi, N., Blaschek, H.P., 2005. Improving performance of a gas strippingbased recovery system to remove butanol from Clostridium beijerinckii fermentation. Bioprocess Biosyst. Eng. 27, 207-214. https://doi.org/10.1007/s00449-005-0403-7.

Ezeji, T.C., Qureshi, N., Blaschek, H.P., 2007. Butanol production from agricultural residues: impact of degradation products on Clostridium beijerinckii growth and butanol fermentation. Biotechnol. Bioeng. 97, 1460-1469. https://doi.org/10.1002/bit.21373.

Fu, C., Cai, D., Hu, S., Miao, Q., Wang, Y., Qin, P., Wang, Z., Tan, T., 2016. Ethanol fermentation integrated with PDMS composite membrane: An effective process. Bioresource Technol. 200, 648-657. https://doi.org/10.1016/j.biortech.2015.09.117.

Gao, K., Rehmann, L., 2016. Combined detoxification and in-situ product removal by a single resin during lignocellulosic butanol production. Sci. Rep. 6, 30533. https://doi.org/10.1038/srep30533.

Gottumukkala, L.D., Haigh, K., Görgens, J., 2017. Trends and advances in conversion of lignocellulosic biomass to biobutanol: Microbes, bioprocesses and industrial viability. Renew. Sust. Energ. Rev. 76, 963-973. https://doi.org/10.1016/j.rser.2017.03.030.

Grisales, V.H., Olivar, G., 2018. Economic optimization of in situ extraction of inhibitors in acetoneethanol-butanol (ABE) fermentation from lignocellulose. Process Biochem. 70, 1-8. https://doi.org/10.1016/j.procbio.2018.04.014. 
Hijosa-Valsero, M., Paniagua-García, A.l., DíezAntolínez, R., 2017. Biobutanol production from apple pomace: the importance of pretreatment methods on the fermentability of lignocellulosic agro-food wastes. Appl. Microbiol. Biot. 101, 80418052. https://doi.org/10.1007/s00253-017-8522z.

Hijosa-Valsero, M., Paniagua-García, A.l., DíezAntolínez, R., 2018a. Industrial potato peel as a feedstock for biobutanol production. New Biotechnol. 46, 54-60. https://doi.org/10.1016/j.nbt.2018.07.002.

Hijosa-Valsero, M., Garita-Cambronero, J., PaniaguaGarcía, A.l., Díez-Antolínez, R., 2018b. Biobutanol production from coffee silverskin. Microb. Cell Fact. 17, 154. https://doi.org/10.1186/s12934-0181002-z.

Lin, S.-H., Juang, R.-S., 2009. Adsorption of phenol and its derivatives from water using synthetic resins and low-cost natural adsorbents: A review. J. Environ. Manage. 90, 1336-1349. https://doi.org/10.1016/j.jenvman.2008.09.003.

Liu, Z.-Y., Yao, X.-Q., Zhang, Q., Liu, Z., Wang, Z.-J., Zhang, Y.Y., Li, F.-L., 2017. Modulation of the acetone/butanol ratio during fermentation of corn stover-derived hydrolysate by Clostridium beijerinckii strain NCIMB 8052. Appl. Environ. Microbiol. 83, e03386-16. https://doi.org/10.1128/AEM.03386-16.

Lu, K.M., Chiang, Y.S., Wang, Y.R., Chein, R.Y., Li, S.Y., 2016. Performance of fed-batch acetone-butanolethanol $(A B E)$ fermentation coupled with the integrated in situ extraction-gas stripping process and the fractional condensation. J. Taiwan Inst. Chem. E. 60, 119-123. https://doi.org/10.1016/j.jtice.2015.10.044.

Malmierca, S., Díez-Antolínez, R., Paniagua, A.l., Martín, M., 2017. Technoeconomic study of $A B$ biobutanol production: Part 1: Biomass pretreatment and hydrolisis. Ind. Eng. Chem. Res. 56, 1518-1524. https://doi.org/10.1021/acs.iecr.6b02943.

Mussatto, S.I., Roberto, I.C., 2004. Alternatives for detoxification of diluted-acid lignocellulosic hydrolyzates for use in fermentative processes: a review. Bioresource Technol. 93, 1-10. https://doi.org/10.1016/j.biortech.2003.10.005.

Nanda, S., Golemi-Kotra, D., McDermott, J.C., Dalai, A., Gökalp, I., Kozinski, J.A., 2017. Fermentative production on butanol: Perspectives on synthetic biology. New Biotechnol. 37(B), 210-221. https://doi.org/10.1016/j.nbt.2017.02.006.

Outram, V., Lalander, C.-A., Lee, J.G.M., Davis, E.T., Harvey, A.P., 2016. A comparison of the energy use of in situ product recovery techniques for the Acetone Butanol Ethanol fermentation. Bioresource Technol. 220, 590-600. https://doi.org/10.1016/j.biortech.2016.09.002.
Paniagua-García, A.l., Hijosa-Valsero, M., DíezAntolínez, R., Sánchez, M.E., Coca, M., 2018. Enzymatic hydrolysis and detoxification of lignocellulosic biomass are not always necessary for ABE fermentation: The case of Panicum virgatum. Biomass Bioenerg. 116, 131-139. https://doi.org/10.1016/j.biombioe.2018.06.006.

Parekh, S.R., Parekh, R.S., Wayman, M., 1988. Ethanol and butanol production by fermentation of enzymatically saccharified $\mathrm{SO}_{2}$-prehydrolysed lignocellulosics. Enzyme Microb. Technol. 10, 660668. https://doi.org/10.1016/0141-0229(88)900579.

Patraşcu, I., Bîldea, C.S., Kiss, A.A., 2017. Eco-efficient butanol separation in the $A B E$ fermentation process. Sep. Purif. Technol. 177, 49-61. https://doi.org/10.1016/j.seppur.2016.12.008.

Qureshi, N., Blaschek, H.P., 1999. Butanol recovery from model solution/fermentation broth by pervaporation: evaluation of membrane performance. Biomass Bioenerg. 17, 175-184. https://doi.org/10.1016/S0961-9534(99)00030-6.

Qureshi, N., Blaschek, H.P., 2001. Recovery of butanol from fermentation broth by gas stripping. Renew. Energ. 22, 557-564. https://doi.org/10.1016/S0960-1481(00)00108-7.

Qureshi, N., Saha, B.C., Hector, R.E., Dien, B., Hughes, S., Liu, S., Iten, L., Bowman, M.J., Sarath, G., Cotta, M.A., 2010. Production of butanol (a biofuel) from agricultural residues: Part II - Use of corn stover and switchgrass hydrolysates. Biomass Bioenerg. 34, 566-571. https://doi.org/10.1016/j.biombioe.2009.12.023.

Qureshi, N., Saha, B.C., Cotta, M.A., Singh, V., Liu, S., Ezeji, T.C., 2014. Process integration for simultaneous saccharification, fermentation, and recovery (SSFR): Production of butanol from corn stover using Clostridium beijerinckii P260. Bioresource Technol. 154, 222-228. https://doi.org/10.1016/j.biortech.2013.11.080.

Sainio, T., Turku, I., Heinonen, J., 2011. Adsorptive removal of fermentation inhibitors from concentrated acid hydrolyzates of lignocellulosic biomass. Bioresource Technol. 102, 6048-6057. https://doi.org/10.1016/j.biortech.2011.02.107.

Sarangi, P.K., Nanda, S., 2018. Recent developments and challenges of acetone-butanol-ethanol fermentation, in: Sarangi, P., Nanda, S., Mohanty, P. (Eds.), Recent advancements in biofules and bioenergy utilization. Springer, Singapore, pp. 111123. https://doi.org/10.1007/978-981-13-13073. 5.

Schwartz, T.J., Lawoko, M., 2010. Removal of acidsoluble lignin from biomass extracts using amberlite XAD-4 resin. BioResources 5, 2337-2347. https://bioresources.cnr.ncsu.edu/BioRes 05/BioRe s_05_4_2337_Schwartz_L_Remov_Acid_Sol_Lignin_E xtracts Amberlite 1145.pdf. 
Shaheen, R., Shirley, M., Jones, D.T., 2000. Comparative fermentation studies of industrial strains belonging to four species of solvent-producing clostridia. J. Mol. Microb. Biotech. 2, 115-124. https://www.caister.com/jmmb/v/v2/v2n1/17.pdf.

Shukor, H., Al-Shorgani, N.K.N., Abdeshahian, P., Hamid, A.A., Anuar, N., Abd Rahman, N., Kalil, M.S., 2014. Production of butanol by Clostridium saccharoperbutylacetonicum N1-4 from palm kernel cake in acetone-butanol-ethanol fermentation using an empirical model. Bioresource Technol. 170, 565-573. https://doi.org/10.1016/j.biortech.2014.07.055.

Staggs, K.W., Nielsen, D.R., 2015. Improving n-butanol production in batch and semi-continuous processes through integrated product recovery. Process Biochem. 50, 1487-1498. https://doi.org/10.1016/j.procbio.2015.06.009.

Tang, C., Chen, Y., Liu, J., Shen, T., Cao, Z., Shan, J., Zhu, C., Ying, H., 2017. Sustainable biobutanol production using alkali-catalyzed organosolv pretreated cornstalks. Ind. Crop. Prod. 95, 383-392. https://doi.org/10.1016/j.indcrop.2016.10.048.

Truong, K.N., Blackburn, J.W., 1984. The stripping of organic chemicals in biological treatment processes. Environ. Prog. 3(3), 143-152. https://doi.org/10.1002/ep.670030304.

Ujor, V., Okonkwo, C., Ezeji, T.C., 2016. Unorthodox methods for enhancing solvent production in solventogenic Clostridium species. Appl. Microbiol. Biotechnol. 100, 1089-1099. https://doi.org/10.1007/s00253-015-7166-0.

de Vrije, T., Budde, M., van der Wal, H., Claassen, P.A.M., López-Contreras, A.M., 2013. "In situ" removal of isopropanol, butanol and ethanol from fermentation broth by gas stripping. Bioresource Technol. 137, 153-159. https://doi.org/10.1016/j.biortech.2013.03.098.

Wang, L., Chen, H., 2011. Increased fermentability of enzymatically hydrolyzed steam-exploded corn stover for butanol production by removal of fermentation inhibitors. Process Biochem. 46, 604607. https://doi.org/10.1016/j.procbio.2010.09.027.

Weil, J.R., Dien, B., Bothast, R., Hendrickson, R., Mosier, N.S., Ladisch, M.R., 2002. Removal of fermentation inhibitors formed during pretreatment of biomass by polymeric adsorbents. Ind. Eng. Chem. Res. 41, 6132-6138. https://doi.org/10.1021/ie0201056.

Xu, G., Ding, J., Han, R., Dong, J., Ni, Y., 2016. Enhancing cellulose accessibility of corn stover by deep eutectic solvent pretreatment for butanol fermentation. Bioresource Technol. 203, 364-369. https://doi.org/10.1016/j.biortech.2015.11.002

Xue, C., Zhao, J., Liu, F., Lu, C., Yang, S.-T., Bai, F.-W., 2013a. Two-stage in situ gas stripping for enhanced butanol fermentation and energy-saving product recovery. Bioresource Technol. 135, 396-
402.

https://doi.org/10.1016/j.biortech.2012.07.062.

Xue, C., Zhao, J.-B., Chen, L.-J., Bai, F.-W., Yang, S.-T., Sun, J.-X., 2014. Integrated butanol recovery for an advanced biofuel: current state and prospects. Appl. Microbiol. Biotechnol. 98, 3463-3474. https://doi.org/10.1007/s00253-014-5561-6.

Xue, C., Zhao, X.-Q., Liu, C.-G., Chen, L.-J., Bai, F.-W., 2013b. Prospective and development of butanol as an advanced biofuel. Biotechnol. Adv. 31, 15751584.

https://doi.org/10.1016/j.biotechadv.2013.08.004.

Xue, C., Wang, Z., Wang, S., Zhang, X., Chen, L., Mu, Y., Bai, F., 2016a. The vital role of citrate buffer in acetone-butanol-ethanol (ABE) fermentation using corn stover and high-efficient product recovery by vapor stripping-vapor permeation (VSVP) process. Biotechnol. Biofuels 9, 146. https://doi.org/10.1186/s13068-016-0566-2.

Xue, C., Liu, F., Xu, M., Zhao, J., Chen, L., Ren, J., Bai, F., Yang, S.-T., 2016b. A novel in situ gas strippingpervaporation process integrated with acetonebutanol-ethanol fermentation for hyper n-butanol production. Biotechnol. Bioeng. 113, 120-129. https://doi.org/10.1002/bit.25666.

Xue, C., Liu, F., Xu, M., Tang, I.-C., Zhao, J., Bai, F., Yang, S.-T., 2016c. Butanol production in acetonebutanol-ethanol fermentation with in situ product recovery by adsorption. Bioresource Technol. 219, 158-168. https://doi.org/10.1016/j.biortech.2016.07.111.

Xue, C., Zhao, J., Chen, L., Yang, S.-T., Bai, F., 2017. Recent advances and state-of-the-art strategies in strain and process engineering for biobutanol production by Clostridium acetobutylicum. Biotechnol. Adv. 35, 310-322. https://doi.org/10.1016/j.biotechadv.2017.01.007.

Yerushalmi, L., Volesky, B., 1987. Culture conditions for growth and solvent biosynthesis by a modified Clostridium acetobutylicum. Appl. Microbiol. Biotechnol. 25, 513-20. https://doi.org/10.1007/BF00252009.

Zhang, X., Feng, X., Zhang, H., Wei, Y., 2018. Utilization of steam-exploded corn straw to produce biofuel butanol via fermentation with a newly selected strain of Clostridium acetobutylicum. BioResources 13(3), 5805-5817. https://bioresources.cnr.ncsu.edu/wpcontent/uploads/2018/06/Biores_13_3_5805_Zhan g_FZ_Utilization_Steam_Explod_CornStraw Butanol Fermentation 13860.pdf.

Zhang, Y., Hou, T., Li, B., Liu, C., Mu, X., Wang, H., 2014. Acetone-butanol-ethanol production from corn stover pretreated by alkaline twin-screw extrusion pretreatment. Bioprocess Biosyst. Eng. 37, 913921. https://doi.org/10.1007/s00449-013-1063-7. 


\section{APPENDIX}

\section{Strain comparison}
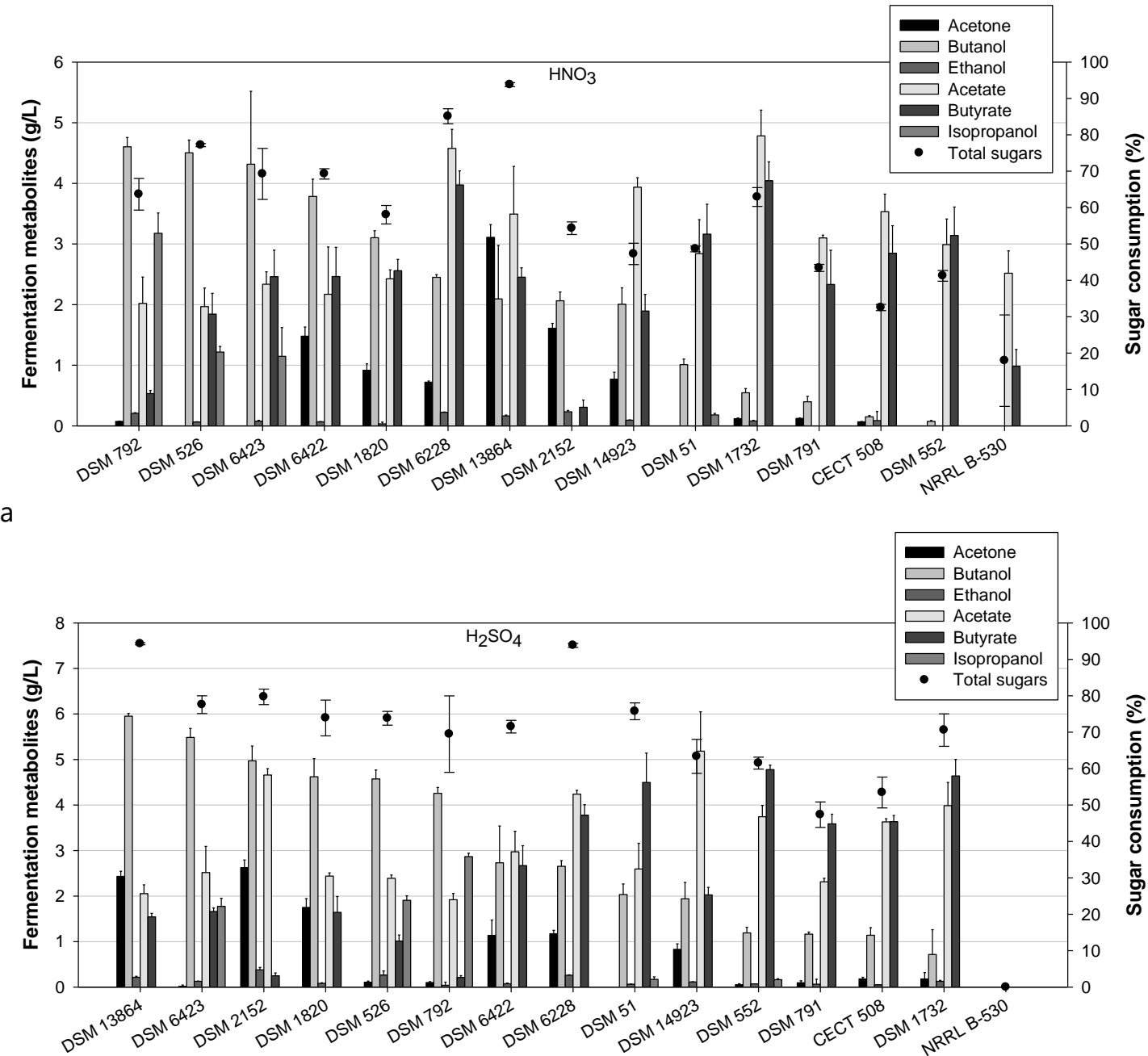

b

Figure A1. Sugar consumption and ABE parameters for a 96-h fermentation of non-detoxified corn stover hydrolysates (pretreatment $125^{\circ} \mathrm{C}, 5 \mathrm{~min}, 0.89 \% \mathrm{w} / \mathrm{w}$ acid) by several Clostridium strains. a) Pretreatment with $\mathrm{HNO}_{3}$. b) Pretreatment with $\mathrm{H}_{2} \mathrm{SO}_{4}$.

\section{Optimisation of fermentation conditions for non-detoxified corn stover hydrolysates}

\section{Plackett-Burman experimental design}

The most adequate nutrients and fermentation conditions for $C$. saccharobutylicum DSM 13864 were evaluated. The results of the Plackett-Burman experiments for nutrient optimisation are shown in Tables $\mathrm{A} 1, \mathrm{~A} 2$ and $\mathrm{A} 3$. Butanol concentrations for the twelve Plackett-Burman experiments ranged between 0.11 and $6.21 \mathrm{~g} / \mathrm{L}$, depending on the nutrient composition (Table A1). The best fitting was obtained when $\mathrm{MnSO}_{4} \cdot 7 \mathrm{H}_{2} \mathrm{O}, \mathrm{FeSO}_{4} \cdot 7 \mathrm{H}_{2} \mathrm{O}, \mathrm{ZnSO}_{4} \cdot 7 \mathrm{H}_{2} \mathrm{O}$ and $\mathrm{CaCO}_{3}$ were removed from the model (Table A2, Table A3). There were three variables with a negative effect (negative sign, Table A2) which were cysteine, $\mathrm{ZnSO}_{4} \cdot 7 \mathrm{H}_{2} \mathrm{O}$ and $\mathrm{CaCO}_{3}$. These variables should be set at the lowest value of their respective range for further experiments. For cysteine and $\mathrm{ZnSO}_{4} \cdot 7 \mathrm{H}_{2} \mathrm{O}$, their lowest value is zero (Table A1) and as a consequence they should be removed from the nutrient cocktail. Regarding $\mathrm{CaCO}_{3}$, its lowest value in the experiment was $1 \mathrm{~g} / \mathrm{L}$ (Table A1). It would be interesting to figure out which would be the most 
appropriate concentration of $\mathrm{CaCO}_{3}$ for the fermentation; therefore, the optimal concentration of this salt will be assessed in the RSM experiment. The nutrients yeast extract, $\mathrm{KH}_{2} \mathrm{PO}_{4}, \mathrm{~K}_{2} \mathrm{HPO}_{4}$ and $\mathrm{NH}_{4} \mathrm{Cl}$ had a positive and significant effect (Table A3); thus these compounds were selected and their concentrations were established at their highest range value for the next experiments. The salts $\mathrm{MnSO}_{4} \cdot 7 \mathrm{H}_{2} \mathrm{O}_{\text {, }}$ $\mathrm{MgSO}_{4} \cdot 7 \mathrm{H}_{2} \mathrm{O}$ and $\mathrm{FeSO}_{4} \cdot 7 \mathrm{H}_{2} \mathrm{O}$ had a positive (but not significant, $\mathrm{p}>0.05$ ) effect, and it was decided to keep them in the nutrient cocktail at the highest value in their concentration range. According to these reasons, yeast extract, $\mathrm{KH}_{2} \mathrm{PO}_{4}, \mathrm{~K}_{2} \mathrm{HPO}_{4}, \mathrm{NH}_{4} \mathrm{Cl}, \mathrm{MgSO}_{4} \cdot 7 \mathrm{H}_{2} \mathrm{O}, \mathrm{MnSO}_{4} \cdot 7 \mathrm{H}_{2} \mathrm{O}$ and $\mathrm{FeSO}_{4} \cdot 7 \mathrm{H}_{2} \mathrm{O}$ were included in the fixed nutrient cocktail which would be used in the RSM experiment (see concentrations in Table A4).

Table A1. Experimental conditions of the Plackett-Burman experiment, and butanol concentrations obtained for each condition for the fermentation of corn stover hydrolysates $\left(125^{\circ} \mathrm{C}, 5 \mathrm{~min}, 0.89 \% \mathrm{w} / \mathrm{w} \mathrm{H} \mathrm{SO}_{4}\right)$ by the strain DSM 13864.

\begin{tabular}{|c|c|c|c|c|c|c|c|c|c|c|c|}
\hline & \multicolumn{10}{|c|}{ Independent variables (g/L) } & \multirow{2}{*}{$\begin{array}{c}\text { Response (g/L) } \\
\text { Butanol }\end{array}$} \\
\hline Plackett-Burman experiment & 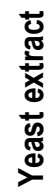 & 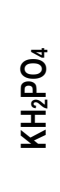 & $\begin{array}{l}\text { 유 } \\
\text { 폻 } \\
\text { }\end{array}$ & $\begin{array}{l}\overline{0} \\
\bar{y}\end{array}$ & 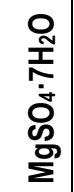 & 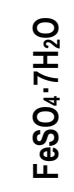 & 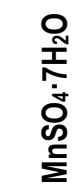 & 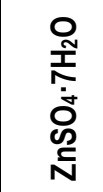 & 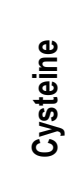 & ర్ల్ర & \\
\hline 1 & 1 & 1 & 1 & 2.1 & 0 & 0.01 & 0.01 & 0 & 0.5 & 1 & 4.85 \\
\hline 2 & 5 & 1 & 0 & 2.1 & 0.2 & 0 & 0.01 & 0 & 0 & 1 & 6.21 \\
\hline 3 & 5 & 1 & 1 & 0 & 0.2 & 0.01 & 0 & 0.001 & 0 & 1 & 6.05 \\
\hline 4 & 5 & 0 & 0 & 0 & 0.2 & 0.01 & 0.01 & 0 & 0.5 & 10 & 0.68 \\
\hline 5 & 1 & 1 & 0 & 0 & 0 & 0.01 & 0.01 & 0.001 & 0 & 10 & 0.11 \\
\hline 6 & 1 & 0 & 0 & 2.1 & 0.2 & 0.01 & 0 & 0.001 & 0.5 & 1 & 0.38 \\
\hline 7 & 5 & 0 & 1 & 0 & 0 & 0 & 0.01 & 0.001 & 0.5 & 1 & 0.16 \\
\hline 8 & 5 & 0 & 1 & 2.1 & 0 & 0.01 & 0 & 0 & 0 & 10 & 5.19 \\
\hline 9 & 1 & 1 & 1 & 0 & 0.2 & 0 & 0 & 0 & 0.5 & 10 & 0.43 \\
\hline 10 & 5 & 1 & 0 & \begin{tabular}{|l|l|}
2.1 \\
\end{tabular} & 0 & 0 & 0 & 0.001 & 0.5 & 10 & 3.54 \\
\hline 11 & 1 & 0 & 1 & 2.1 & 0.2 & 0 & 0.01 & 0.001 & 0 & 10 & 5.16 \\
\hline 12 & 1 & 0 & 0 & 0 & 0 & 0 & 0 & 0 & 0 & 1 & 0.16 \\
\hline
\end{tabular}

Table A2. Effects of each independent variable on the response variable (butanol concentration) in the Plackett-Burman experimental design with corn stover acid hydrolysate fermented by DSM 13864.

\begin{tabular}{|c|c|c|c|c|c|}
\hline Term & Effect & Coefficient (uncoded) & SE Coef & $\mathrm{T}$ & $p$ \\
\hline Constant & & -0.90083 & 0.6633 & 4.14 & 0.151 \\
\hline Yeast extract & 1.790 & 0.447500 & 0.6633 & 1.35 & 0.406 \\
\hline $\mathrm{KH}_{2} \mathrm{PO}_{4}$ & 1.577 & 1.57557 & 0.6633 & 1.19 & 0.445 \\
\hline $\mathrm{K}_{2} \mathrm{HPO}_{4}$ & 1.792 & 1.79333 & 0.6633 & 1.35 & 0.405 \\
\hline $\mathrm{NH}_{4} \mathrm{Cl}$ & 2.957 & 1.40794 & 0.6633 & 2.23 & 0.269 \\
\hline $\mathrm{MgSO}_{4} \cdot 7 \mathrm{H}_{2} \mathrm{O}$ & 0.817 & 4.08333 & 0.6633 & 0.62 & 0.649 \\
\hline $\mathrm{FeSO}_{4} \cdot 7 \mathrm{H}_{2} \mathrm{O}$ & 0.267 & 26.667 & 0.6633 & 0.20 & 0.874 \\
\hline $\mathrm{MnSO}_{4} \cdot 7 \mathrm{H}_{2} \mathrm{O}$ & 0.237 & 23.667 & 0.6633 & 0.18 & 0.888 \\
\hline $\mathrm{ZnSO}_{4} \cdot 7 \mathrm{H}_{2} \mathrm{O}$ & -0.353 & -353.33 & 0.6633 & \begin{tabular}{|l|}
-0.27 \\
\end{tabular} & 0.834 \\
\hline Cysteine & -2.140 & -4.28000 & 0.6633 & -1.61 & 0.353 \\
\hline $\mathrm{CaCO}_{3}$ & -0.450 & -0.05000 & 0.6633 & -0.34 & 0.792 \\
\hline \multicolumn{2}{|l|}{$S=2.29785$} & \multicolumn{2}{|l|}{ PRESS $=760.339$} & & \\
\hline R-square $=92.99 \%$ & & R-square (pred.) $=0 \%$ & & R-sqI & $89 \%$ \\
\hline
\end{tabular}


Table A3. Effects of each independent variable on the response variable (butanol concentration) in the Plackett-Burman experimental design with corn stover acid hydrolysate fermented by DSM 13864, after removing non-significant independent variables.

\begin{tabular}{|l|l|l|l|l|l|}
\hline Term & Effect & Coefficient (uncoded) & SE Coef & T & p \\
\hline Constant & & -1.10083 & 0.3328 & 8.24 & 0.000 \\
\hline Yeast extract & 1.790 & 0.447500 & 0.3328 & 2.69 & 0.043 \\
\hline $\mathrm{KH}_{2} \mathrm{PO}_{4}$ & 1.577 & 1.57667 & 0.3328 & 2.37 & 0.064 \\
\hline $\mathrm{K}_{2} \mathrm{HPO}_{4}$ & 1.793 & 1.79333 & 0.3328 & 2.69 & 0.043 \\
\hline $\mathrm{NH}_{4} \mathrm{Cl}$ & 2.957 & 1.40794 & 0.3328 & 4.44 & 0.007 \\
\hline $\mathrm{MgSO}_{4} \cdot \mathbf{7} \mathrm{H}_{2} \mathrm{O}$ & 0.817 & 4.08333 & 0.3328 & 1.23 & 0.274 \\
\hline Cysteine & -2.14 & -4.28000 & 0.3328 & -3.22 & 0.024 \\
\hline $\mathbf{S}=1.15270$ & PRESS $=\mathbf{3 8 . 2 6 6 8}$ & \multicolumn{2}{l|}{ R-square (adjusted) $\mathbf{= 8 0 . 6 0 \%}$} \\
\hline R-square $=\mathbf{9 1 . 1 8 \%}$
\end{tabular}

\section{Response surface methodology (RSM)}

In the RSM experiment, fermentation temperature, initial $\mathrm{pH}$ and $\mathrm{CaCO}_{3}$ concentration were optimised (Table A4). Butanol concentrations under the fifteen tested conditions from the RSM ranged between 0 and $6.55 \mathrm{~g} / \mathrm{L}$ (Table A5). According to regression coefficients (Table A6) and analysis of variance (Table A7), the model explained $87.75 \%$ of the variation, but its predicted R-square value of $0 \%$ indicated that the model was overfit. The removal of non-significant variables (with $p>0.05$ ) to generate new models did not improve $R$ values (data not shown). Therefore, the information from Table A6 and Table A7 was used to create an equation to estimate butanol concentrations from independent variables:

Butanol $(\mathrm{g} / \mathrm{L})=-54.2315+0.006 \cdot \mathrm{T}+20.3297 \cdot \mathrm{pH}+2.8453 \cdot \mathrm{CaCO}_{3}-0.0093 \cdot \mathrm{T}^{2}-1.6558 \cdot \mathrm{pH}^{2}-0.0652 \cdot \mathrm{CaCO}_{3}{ }^{2}$ $+0.0208 \cdot \mathrm{T} \cdot \mathrm{pH}+0.0067 \cdot \mathrm{T} \cdot \mathrm{CaCO}_{3}-0.3656 \cdot \mathrm{pH} \cdot \mathrm{CaCO}_{3}$

where $T$ is the fermentation temperature $\left({ }^{\circ} \mathrm{C}\right), \mathrm{pH}$ is the initial $\mathrm{pH}$ value and $\mathrm{CaCO}_{3}$ is the concentration of calcium carbonate $(\mathrm{g} / \mathrm{L})$ added to the fermentation broth. This equation was used to mathematically determine the optimal values of temperature, $\mathrm{pH}$ and $\mathrm{CaCO}_{3}$ concentration which would maximise butanol production. The calculated optimum answer established that it would be possible to produce 7.56 $\mathrm{g} / \mathrm{L}$ butanol when working at $28{ }^{\circ} \mathrm{C}, \mathrm{pH} 5.42$ and $8.0 \mathrm{~g} / \mathrm{L} \mathrm{CaCO}$. These optimal conditions, as well as the nutrient concentrations established in the Plackett-Burman experiment, have been summarised in Table 2 (optimised conditions - O). In order to validate the RSM model, this optimal point was experimentally tested by fermenting corn stover hydrolysates under these optimised conditions (Table 2). The results of model validation yielded a butanol concentration of $5.38 \pm 0.21 \mathrm{~g} / \mathrm{L}$, which is far from the estimated value $(7.56 \mathrm{~g} / \mathrm{L})$. In addition, other fermentation experiments were performed on different days under similar circumstances obtaining variable butanol concentrations in the range of 4.49-6.38 g/L.

Table A4. Conditions of the RSM experiment for the fermentation of corn stover hydrolysates by DSM 13864. In the case of RSM independent variables, axial values are indicated.

\begin{tabular}{|l|l|l|l|}
\hline Independent variable of RSM & \multicolumn{2}{l|}{ Fixed parameters } \\
\hline Variable & Range & Maximum (g/L) & Concentration $(\mathbf{g} / \mathbf{L})$ \\
\hline Temperature $\left({ }^{\circ} \mathrm{C}\right)$ & $28-40$ & Yeast extract & 5 \\
\hline Initial pH & $5-7$ & $\mathrm{KH}_{2} \mathrm{PO}_{4}$ & 1 \\
\hline $\mathrm{CaCO}_{3}(\mathbf{g} / \mathbf{L})$ & $\mathrm{K}_{2} \mathrm{HPO}_{4}$ & 1 \\
\hline & $1-10$ & $\mathrm{NH}_{4} \mathrm{Cl}$ & 2.1 \\
\hline & & $\mathrm{MgSO}_{4} \cdot 7 \mathrm{H}_{2} \mathrm{O}$ & 0.2 \\
\hline & & $\mathrm{FeSO}_{4} \cdot 7 \mathrm{H}_{2} \mathrm{O}$ & 0.01 \\
\hline & & $\mathrm{MnSO}_{4} \cdot 7 \mathrm{H}_{2} \mathrm{O}$ & 0.01 \\
\hline & & $\mathrm{ZnSO}_{4} \cdot 7 \mathrm{H}_{2} \mathrm{O}$ & 0 \\
\hline & & Cysteine & 0 \\
\hline & &
\end{tabular}


Table A5. Butanol concentrations obtained for each of the experimental conditions of the RSM, for the fermentation of corn stover hydrolysates $\left(125^{\circ} \mathrm{C}, 5 \mathrm{~min}, 0.89 \% \mathrm{w} / \mathrm{w} \mathrm{H}_{2} \mathrm{SO}_{4}\right)$ by the strain DSM 13864.

\begin{tabular}{|l|l|l|l|l|}
\hline & \multicolumn{3}{l|}{ Independent variables } & Response variable \\
\hline RSM experiment & Temperature $\left({ }^{\circ} \mathbf{C}\right)$ & $\mathbf{p H}$ & $\mathrm{CaCO}_{3}(\mathbf{g} / \mathbf{L})$ & Butanol $(\mathbf{g} / \mathbf{L})$ \\
\hline $\mathbf{1}$ & 34 & 5.0 & 10 & 6.55 \\
\hline $\mathbf{2}$ & 28 & 6.0 & 1 & 6.38 \\
\hline $\mathbf{3}$ & 40 & 6.0 & 10 & 0 \\
\hline $\mathbf{4}$ & 34 & 6.0 & 5.5 & 5.91 \\
\hline $\mathbf{5}$ & 34 & 6.0 & 5.5 & 3.73 \\
\hline $\mathbf{6}$ & 40 & 5.0 & 5.5 & 0.06 \\
\hline $\mathbf{7}$ & 28 & 7.0 & 5.5 & 5.04 \\
\hline $\mathbf{8}$ & 28 & 5.0 & 5.5 & 5.49 \\
\hline $\mathbf{9}$ & 40 & 7.0 & 5.5 & 0.11 \\
\hline $\mathbf{1 0}$ & 34 & 6.0 & 5.5 & 4.36 \\
\hline $\mathbf{1 1}$ & 34 & 7.0 & 10 & 0.09 \\
\hline $\mathbf{1 2}$ & 40 & 6.0 & 1 & 0 \\
\hline $\mathbf{1 3}$ & 28 & 6.0 & 10 & 5.66 \\
\hline $\mathbf{1 4}$ & 34 & 7.0 & 1 & 0.12 \\
\hline $\mathbf{1 5}$ & 34 & 5.0 & 1 & 0 \\
\hline
\end{tabular}

Table A6. Estimated regression coefficients of butanol in the RSM experiment for the fermentation of corn stover hydrolysates $\left(125^{\circ} \mathrm{C}, 5 \mathrm{~min}, 0.89 \% \mathrm{w} / \mathrm{w} \mathrm{H}_{2} \mathrm{SO}_{4}\right.$ ) by the strain DSM 13864.

\begin{tabular}{|c|c|c|c|c|}
\hline Term & Coefficient (uncoded) & $\begin{array}{l}\text { Standard } \\
\text { error coef. }\end{array}$ & $\mathrm{T}$ & $p$ \\
\hline Constant & -54.2315 & 52.1633 & -1.040 & 0.346 \\
\hline Temperature $\left({ }^{\circ} \mathrm{C}\right)$ & 0.0060 & 1.8448 & 0.003 & 0.998 \\
\hline $\mathrm{pH}$ & 20.3297 & 11.4666 & 1.773 & 0.136 \\
\hline $\mathrm{CaCO}_{3}$ & 2.8453 & 1.6014 & 1.777 & 0.136 \\
\hline $\begin{array}{l}\text { Temperature }\left({ }^{\circ} \mathrm{C}\right){ }^{*} \\
\text { Temperature }\left({ }^{\circ} \mathrm{C}\right)\end{array}$ & -0.0093 & 0.0240 & -0.388 & 0.714 \\
\hline $\mathrm{pH}^{*} \mathrm{pH}$ & -1.6558 & 0.8656 & -1.913 & 0.114 \\
\hline $\mathrm{CaCO}_{3}{ }^{*} \mathrm{CaCO}_{3}$ & -0.0652 & 0.0427 & -1.526 & 0.188 \\
\hline $\begin{array}{l}\text { Temperature }\left({ }^{\circ} \mathrm{C}\right){ }^{*} \\
\mathrm{pH}\end{array}$ & 0.0208 & 0.1386 & 0.150 & 0.886 \\
\hline $\begin{array}{l}\text { Temperature }\left({ }^{\circ} \mathrm{C}\right)^{*} \\
\mathrm{CaCO}_{3}\end{array}$ & 0.0067 & 0.0308 & 0.216 & 0.837 \\
\hline $\mathrm{pH}^{*} \mathrm{CaCO}_{3}$ & -0.3656 & 0.1848 & -1.978 & 0.105 \\
\hline$S=1.66329$ & \multicolumn{2}{|l|}{ PRESS = 186.711} & & \\
\hline R-square $=87.75 \%$ & R-square (pred.) $=0 \%$ & & \multicolumn{2}{|c|}{ R-square (adjusted) $=65.70 \%$} \\
\hline
\end{tabular}

Table A7. Analysis of variance of butanol in the RSM experiment for the fermentation of corn stover hydrolysates $\left(125^{\circ} \mathrm{C}, 5 \mathrm{~min}\right.$, $0.89 \%$ w/w $\mathrm{H}_{2} \mathrm{SO}_{4}$ ) by the strain DSM 13864 .

\begin{tabular}{|l|l|l|l|l|l|l|}
\hline Source & df & $\begin{array}{l}\text { Sum of of squares } \\
\text { squares } \\
\text { Seq. }\end{array}$ & $\begin{array}{l}\text { Mean of } \\
\text { squares } \\
\text { Adjust. }\end{array}$ & F & p \\
\hline Regression & 9 & 99.090 & 99.0903 & 11.0100 & 3.98 & 0.071 \\
\hline Lineal & 3 & 72.603 & 16.9514 & 5.6505 & 2.04 & 0.227 \\
\hline Temperature & 1 & 62.720 & 0.0000 & 0.0000 & 0.00 & 0.998 \\
\hline $\mathrm{pH}$ & 1 & 5.678 & 8.6962 & 8.6962 & 3.14 & 0.136 \\
\hline $\mathrm{CaCO}_{3}$ & 1 & 4.205 & 8.7334 & 8.7334 & 3.16 & 0.136 \\
\hline Quadratic & 3 & 15.471 & 15.4706 & 5.1569 & 1.86 & 0.253 \\
\hline $\begin{array}{l}\text { Temperature } \\
\text { Temperature }\end{array}$ & 1 & 0.057 & 0.4164 & 0.4164 & 0.15 & 0.714 \\
\hline $\mathrm{pH}^{*} \mathbf{p H}$ & 1 & 8.972 & 10.1235 & 10.1235 & 3.66 & 0.114 \\
\hline
\end{tabular}




\begin{tabular}{|l|l|l|l|l|l|l|}
\hline Source & df & $\begin{array}{l}\text { Sum of } \\
\text { squares } \\
\text { Seq. }\end{array}$ & $\begin{array}{l}\text { Sum of squares } \\
\text { Adjust. }\end{array}$ & $\begin{array}{l}\text { Mean of } \\
\text { squares } \\
\text { Adjust. }\end{array}$ & $\mathbf{F}$ & $\mathbf{p}$ \\
\hline $\mathrm{CaCO}_{3}{ }^{*} \mathrm{CaCO}_{3}$ & 1 & 6.442 & 6.4416 & 6.4416 & 2.33 & 0.188 \\
\hline Interaction & 3 & 11.016 & 11.0162 & 3.6721 & 1.33 & 0.364 \\
\hline Temperature ${ }^{*} \mathrm{pH}$ & 1 & 0.063 & 0.0625 & 0.0625 & 0.02 & 0.886 \\
\hline $\begin{array}{l}\text { Temperature } \\
\mathrm{CaCO}_{3}\end{array}$ & 1 & 0.130 & 0.1296 & 0.1296 & 0.05 & 0.837 \\
\hline $\mathrm{pH}^{*} \mathrm{CaCO}_{3}$ & 1 & 10.824 & 10.8241 & 10.8241 & 3.91 & 0.105 \\
\hline Residual error & 5 & 13.833 & 13.8327 & 2.7665 & & \\
\hline Lack of fit & 3 & 11.315 & 11.3154 & 3.7718 & 3.00 & 0.260 \\
\hline Pure error & 2 & 2.517 & 2.5173 & 1.2586 & & \\
\hline Total & 14 & 112.923 & & & & \\
\hline
\end{tabular}

\section{Detoxification and choice of strains for detoxified hydrolysates}

As the nature of corn stover detoxified hydrolysates is different from that of non-detoxified hydrolysates, it was decided to check whether the selected strain, additional nutrients and fermentation conditions established for the non-detoxified hydrolysates were also appropriate for the detoxified hydrolysate. Therefore, the three best performing strains for the non-detoxified hydrolysate (DSM 13864, DSM 6423 and DSM 2152; see section 3.2) were compared to ferment the detoxified hydrolysate of the resin Dowex ${ }^{\circledR}$ Optipore ${ }^{\circledR} \mathrm{SD}-2$, under the two different conditions shown in Table 2 (S and O). This hydrolysate had been prepared with $0.89 \% \mathrm{H}_{2} \mathrm{SO}_{4} \mathrm{w} / \mathrm{w}, 5 \mathrm{~min}, 160{ }^{\circ} \mathrm{C}$. The results of this strain comparison are given in Figure A2.

The highest butanol concentration was obtained by DSM 13864 with optimised conditions $(8.55 \pm 0.07$ $\mathrm{g} / \mathrm{L})$, followed by DSM 13864 with standard conditions $(7.64 \pm 0.03 \mathrm{~g} / \mathrm{L})$, DSM 2152 with standard conditions $(7.17 \pm 0.11 \mathrm{~g} / \mathrm{L})$ and DSM 6423 with standard conditions $(6.44 \pm 0.21 \mathrm{~g} / \mathrm{L})$. The nutrient composition and fermentation conditions that had been optimised for DSM 13864 in the non-detoxified hydrolysate $(O)$ were the most efficient $(p<0.05)$ for DSM 13864 with the detoxified hydrolysate too. On the contrary, standard conditions (S) were the most appropriate for strains DSM 6423 and DSM 2152 with the detoxified hydrolysate $(p<0.05)$. In summary, with this detoxified hydrolysate, butanol production with DSM 13864 and Optimised conditions is statistically superior $(p<0.05)$ to that obtained by DSM 6423 and DSM 2152 under conditions O or S. Therefore, DSM 13864 and its optimised nutrient and fermentation conditions are also valid for detoxified corn stover hydrolysate. 


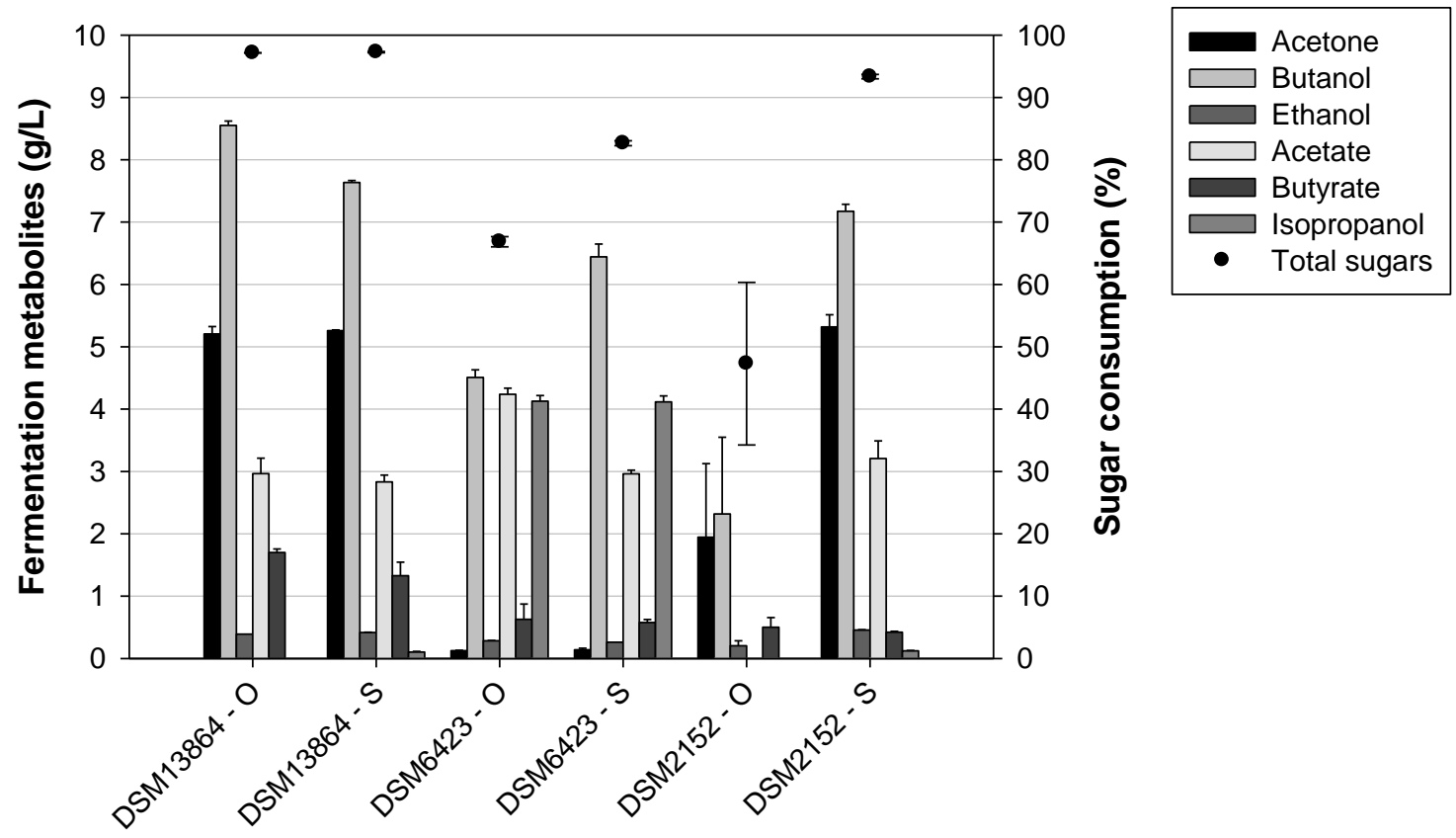

Figure A2. Fermentation of corn stover hydrolysates $\left(0.89 \% \mathrm{H}_{2} \mathrm{SO}_{4} \mathrm{w} / \mathrm{w}, 160^{\circ} \mathrm{C}, 5 \mathrm{~min}\right)$ detoxified with resin Dowex® Optipore $\AA$ SD-2, using C. saccharobutylicum DSM 13864, C. beijerinckii DSM 6423 and C. saccharoperbutylacetonicum DSM 2152, under two different fermentation conditions ( $\mathrm{O}$ and $\mathrm{S}$, see Table 2 ).

Table A8. Fermentation of corn stover hydrolysates before and after detoxification with three adsorption resins with $C$. saccharobutylicum DSM 13864, under two different pretreatment conditions. Note: See Figure 2 for more details.

\begin{tabular}{|c|c|c|c|c|c|}
\hline & Acetone (g/L) & Butanol (g/L) & Ethanol ( $g / L)$ & Acetic acid (g/L) & Butyric acid (g/L) \\
\hline \multicolumn{6}{|c|}{ Pretreatment $125^{\circ} \mathrm{C}$. Fermentation $96 \mathrm{~h}$. } \\
\hline Control & $3.85 \pm 0.12$ & $8.42 \pm 0.45$ & $0.27 \pm 0.01$ & $1.06 \pm 0.37$ & $1.23 \pm 0.08$ \\
\hline Undetoxified & $3.27 \pm 0.32$ & $5.60 \pm 0.74$ & $0.26 \pm 0.02$ & $3.20 \pm 0.18$ & $1.27 \pm 0.07$ \\
\hline Amberlite XAD-4 & $3.91 \pm 0.06$ & $5.62 \pm 0.02$ & $0.30 \pm 0.01$ & $2.29 \pm 0.29$ & $0.88 \pm 0.09$ \\
\hline Dowex Optipore L-493 & $3.77 \pm 0.06$ & $5.38 \pm 0.06$ & $0.29 \pm 0.01$ & $2.52 \pm 0.02$ & $0.89 \pm 0.01$ \\
\hline Dowex Optipore SD-2 & $3.67 \pm 0.07$ & $5.50 \pm 0.06$ & $0.28 \pm 0.01$ & $2.55 \pm 0.03$ & $0.88 \pm 0.02$ \\
\hline \multicolumn{6}{|c|}{ Pretreatment $125^{\circ} \mathrm{C}$. Fermentation $96 \mathrm{~h}$. } \\
\hline Control & $2.99 \pm 0.08$ & $9.35 \pm 0.06$ & $0.23 \pm 0.01$ & $0.82 \pm 0.11$ & $0.72 \pm 0.14$ \\
\hline Undetoxified & $0.00 \pm 0.00$ & $0.12 \pm 0.04$ & $0.00 \pm 0.00$ & $3.92 \pm 0.04$ & $1.04 \pm 0.60$ \\
\hline Amberlite XAD-4 & $5.14 \pm 0.07$ & $8.71 \pm 0.03$ & $0.39 \pm 0.01$ & $2.04 \pm 0.06$ & $1.12 \pm 0.06$ \\
\hline Dowex Optipore L-493 & $5.17 \pm 0.23$ & $8.39 \pm 0.23$ & $0.39 \pm 0.01$ & $2.08 \pm 0.12$ & $1.20 \pm 0.06$ \\
\hline Dowex Optipore SD-2 & $4.75 \pm 0.25$ & $9.02 \pm 0.11$ & $0.39 \pm 0.01$ & $2.17 \pm 0.07$ & $1.26 \pm 0.07$ \\
\hline
\end{tabular}

\begin{tabular}{|c|c|c|c|}
\hline & Sugar consumption (\%) & $Y_{B / S}(g / g)$ & $W_{B}[g /(L \cdot h)]$ \\
\hline \multicolumn{4}{|c|}{ Pretreatment $125^{\circ} \mathrm{C}$. Fermentation $96 \mathrm{~h}$. } \\
\hline Control & $99.2 \pm 1.1$ & $0.223 \pm 0.014$ & $0.088 \pm 0.005$ \\
\hline Undetoxified & $50.6 \pm 5.7$ & $0.296 \pm 0.061$ & $0.058 \pm 0.008$ \\
\hline Amberlite XAD-4 & $95.3 \pm 0.1$ & $0.181 \pm 0.001$ & $0.059 \pm 0.000$ \\
\hline Dowex Optipore L-493 & $95.4 \pm 0.1$ & $0.180 \pm 0.002$ & $0.056 \pm 0.001$ \\
\hline Dowex Optipore SD-2 & $95.7 \pm 0.3$ & $0.181 \pm 0.003$ & $0.057 \pm 0.001$ \\
\hline \multicolumn{4}{|c|}{ Pretreatment $125^{\circ} \mathrm{C}$. Fermentation $96 \mathrm{~h}$. } \\
\hline Control & $85.0 \pm 10.5$ & $0.257 \pm 0.035$ & $0.130 \pm 0.001$ \\
\hline Undetoxified & $3.6 \pm 0.2$ & $0.073 \pm 0.020$ & $0.002 \pm 0.001$ \\
\hline Amberlite XAD-4 & $96.8 \pm 0.1$ & $0.219 \pm 0.01$ & $0.121 \pm 0.000$ \\
\hline Dowex Optipore L-493 & $97.2 \pm 0.0$ & $0.205 \pm 0.005$ & $0.117 \pm 0.003$ \\
\hline Dowex Optipore SD-2 & $97.3 \pm 0.3$ & $0.222 \pm 0.003$ & $0.125 \pm 0.002$ \\
\hline
\end{tabular}

